\title{
北アルプス針ノ木岳・蓮華岳周辺の承河地形と 氷期の地形的雪線高度
}

\author{
伊 藤 真 人*・正木智 幸**
}

要 旨北アルプス中部, 針ノ木岳・蓮華岳周辺の氷河地形の分布を明らかにし, 南北両斜面に扔け る分布や地形的雪線高度のちがいについて比較した。またこの結果を槍・穂高連峰の地形的雪 線高度と比較し, 両地域に扮ける水期の気温差の算出を試又た。

当地域の氷河地形分布は第 3 図の上らにまとめられ，モレーンや水食壁の分布状況から，当 地域では古い方から針ノ木 I 期 IV 期の 4 回の氷河前進期が認められた。これらの前進期に拉 ける氷河分布面積は, 各前進期とも北側斜面の方が広い。地形的雪線高度は, I 期や II 期では北 側斜面の方が高いが，III 期やIV 期になると南側斜面の方が高くなる。また，当地域の氷河分 布面積と地形的雪線高度とを槍・穂高連峰のそれらと比較した結果, 当地域の方が分布面積は 狭く, 地形的雪線高度は低いといら結果となった。次に両地域の気温差について検討した結果, I 期 (滝谷期) で $0.4^{\circ} \mathrm{C}$, II 期 (槍平期) で $0.5^{\circ} \mathrm{C}$, III 期（飛驒沢期 I） で $0.9^{\circ} \mathrm{C}, \mathrm{IV}$ 期 (飛驒沢 期 II）で $1.0^{\circ} \mathrm{C}$ とそれぞれ当地域の方が気温が低くなり, 新しい前進期注ど現在の気温差 $\left(1.2^{\circ} \mathrm{C}\right)$ と変わらない結果となった。

\section{I. はじめに}

日本の山岳地域の氷期の雪線高度については，す でにいくつかの研究がある。小林・星合（1955）と Hoshiai and Kobayashi (1957) は，カール底高度 をもとに氷期の雪線高度を算出し, 自由大気の温度 から推定した現在の雪線高度との比較を行った。ま た小疇（1983）は，化石周氷河地形の分布から氷期 の気温低下量を見積った。一方，地域的な氷河の発 達規模から氷期の雪線高度を論じた報告には，槍。 穂高連峰の大喰沢カールと中の沢カールを氷期の気 候的雪線高度の地形的証跡と考光た式(1956)，中部 山岳地域の新旧二つの水河前進期の氷河分布から, 地域的な水河の発達規模を比較した五百沢 (1979), 黒部五郎岳東側に発達した氷河の質量収支を論じた Ono（1981）や小野（1982）, 槍・穂高連峰の東西斜
面に扮ける氷期の地形的雪線高度を比較した伊藤 (1982) やIto and Vorndran（1983）などがあげら れる。しかし, 詳細な現地調查に基づいて氷河地形 の分布を明らかにし，そこから氷期の雪線高度を地 域的に比較した例は少ない。また南北に連なる日本 の山岳地域では，東側斜面と西側斜面の雪線高度を 比較した研究はあっても, 南側斜面と北側斜面にお ける雪線高度を比較した例は報告されていない。

そこで筆者らは，南北に長い主山稜を有する日本 アルプスのなかで, 部分的ではあるが, 東西に延び る山稜をもち，ぬた，氷河地形の分布も明らかにさ れていない北アルプス中部, 針ノ岳・蓮華岳周辺を 対象地域として氷河地形分布を明らかにするととも に，氷期の氷河を復元し，南北両斜面の地形的雪線 高度の比較, 槍 - 穂高連峰の氷期の地形的雪線高度 との比較を行った。

* 気象庁高層気象台

** 東京学芸大学附属高等学校大泉校舎 


\section{III。研究地域概要}

調查地域は北アルプス中部，針ノ木岳 $(2,820.6 \mathrm{~m})$ から蓮華岳 $(2,798.7 \mathrm{~m})$ に至る主稜線の北側斜面 (北 向斜面) 及び南側斜面 (南向斜面), すなわち篭川上 流部及び高瀬川北葛沢上流部と黒部川針ノ木谷上流 部である(第 1 図)。主稜線は注淁東西方向に延び, 2,750 2,800 m の定高性を有するが，西端の針ノ木 岳東方には鞍部である針ノ木峠 $(2,536 \mathrm{~m})$ が位置す る。

主稜線北側斜面には，マヤクボ沢谷頭部のマヤク ボカールをはじめとし, 赤石沢, 大沢, 丸石沢の谷 頭部の標高 2,450〜2,520 m にカール底状地をもつ カール状地形が発達する。その下流側には，急峻な 斜面を有する開析されたU字谷状地形が標高約 $1,800 \mathrm{~m}$ まで連続する。一方, 主稜線南側斜面の針, 木谷や北葛沢谷頭部では, カール状地形の発達は微



第 1 図 調查地域位置図

等高線は $1,000 \mathrm{~m}, 2,000 \mathrm{~m}, 2,500 \mathrm{~m}$ である。
弱であるが，五百沢（1979）が氷食谷として認めた 針ノ木谷をはじめ, 馬蹄形状やU 字状の開析された 谷が発達する。

森林限界高度は場所によって異なるが, 標高 2,300 〜2,500 m である。それより標高の高い地域におい ては，針ノ木岳付近でトアが，蓮華岳付近で岩屑匍 行斜面がそれぞれ発達する。越年性雪渓は, 篭川本 流上流部（針ノ木雪溪）と北葛沢に分布する。

当地域の地質は第 2 図に示すと抢り, 稜線部に招 いて安山岩, 流紋岩, 火山角砅岩, 凝灰角碩岩など が，下流側では花崗岩などが分布する（松本砂防工 事事務所, 1976 ; 石川, 1982 ; 平林，1982)。

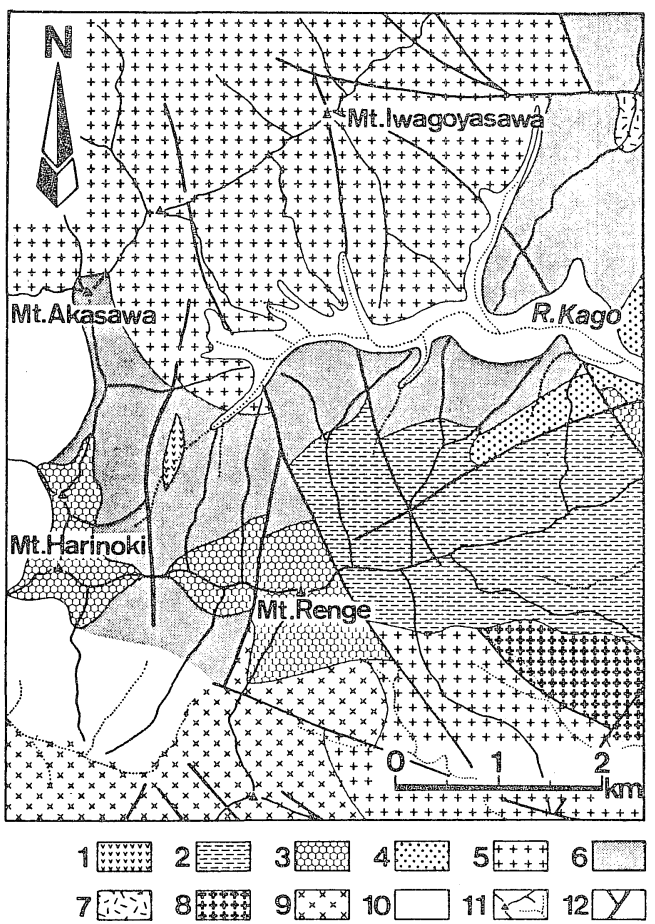

第 2 図 調査地域地質図（石川（1982）を簡略化） 1: 猿すべり文象斑岩, 2 と 3 : 針ノ木一白 沢火山岩類 $(2$ : 流紋岩質〜流紋デイサイト 質溶結凝灰岩, 3: 流紋岩質〜流紋デイサ イト質火山角碟岩～凝灰角碟岩)，4：流紋 岩溶岩, 5 : 金沢花崗岩, 6 と 7 : 爺个岳火 山岩類 (6: 安山岩質〜デイサイト質火砕 岩, 7 : 安山岩溶岩), 8 : 有明花崗岩, 9 : 葛花崗岩, 10 : 未記載地域及び第四系, 11：山稜及び河川, 12 : 断層 


\section{III. 氷河地形の分布}

\section{1. 水河地形の同定}

氷河地形の同定には空中写真判読を用い, 判読結 果を確認するため現地調查と堆積物の分析とを行っ た。詳細な現地調查は，篭川本流とマヤクボ沢，丸 石沢，針ノ木谷について行った。

空中写真判読については，五百沢（1963，1973， 1974）とそれを引用した小野・平川（1974）の手法 を基本とした。すなわち谷頭部で, 氷河の存在した 凹型緩斜面ないし平坦面を発見し，次いでその上方 と側方に急傾斜な侵食地形の存在を求める。そして 下流側にも上記の斜面が連続するかどうかを確認 し, それらに付随するモレーン, 羊群岩, 水食尾根 などを探し出した。

本論では，特に空中写真判読から複数の水河前進 期の存在を摘出するために，カール壁や水食谷壁の 形状とそれらの最下部に分布するモレーンやアウト ウォッシュ段丘（バリートレイン）の位置関係に留 意した。すなわち氷食谷やカール壁に形成される氷 河研磨面（glacial polish, polished surface）の連続 性，谷壁上部の U 字谷谷壁上端（trough edge）と 肩地形（trough shoulder）の高度と連続性，また谷 底に生ずる谷栅（riegel）と小規模な岩石盈地（rock basin）からなる氷食谷階段（valley steps）の発達 状況などを詳細に判読した。そしてこれら複数の侵 食地形の相互関係から, 地形が形成された時期の新 旧を調ベ，さらにモレーンやアウトウォッシュ段丘 との位置関係から水河前進期の存在の吟味を行っ た。例光ば一つの谷に和いて, U 字谷谷壁上端が右 岸, 左岸ともに 2 つちがった高度で連続的に発達 している場合, 最下流部でそれらU 字谷谷壁上端が 消滅する付近にモレーンやアウトウォッシュ段丘を 発見し, 新旧 2 回の氷河前進期を想定するといった 手順をとった。また, 氷河地形の開析の程度や埋積 された状態, 植被状態も重要な判読基準とした。一
方，ティルやアウトウォッシュなどの堆積物が開析 されてしまった場合も当然考光られるため，そのよ らな地域では，氷食地形の分布状態を主な基準とし た。そしてこのような空中写真判読によって得られ た結果に, 後述する現地調查の結果と堆積物の分析 結果を加光て，当地域に括ける氷河前進期の区分を 試み，水河地形分布図（第 3 図）を作成した。

\section{2. 水河前進期の区分}

前節で述べた空中写真判読と現地調查, 扔よび堆 積物の分析結果から，当地域に捻いてはほぼ 4 回の 氷河前進期が認められることがわかった。そこでこ れらの水河前進期を古い方から, 針ノ木 I 期, 針ノ木 II 期, 針ノ木 III 期, 針ノ木 IV 期と呼ぶことにする。 各水河前進期に扮ける氷河地形分布の概要を, 第 3 図に基づいて以下にまとめる。

I 期：I期を代表するようなティルは確認できて いないが，大沢出合の篭川本流右岸側の堆積物，ま た赤沢や鳴沢では篭川本流との合流部付近のモレー ン状地形, 北葛沢 $\mathrm{P}$ 沢 R $\mathrm{R}$ 沢下流部のモレーン状地 形などが、この前進期に形成されたものと判断した。 この前進期に形成された最も開析の進んでいる氷河 研磨面状の水食壁は, 篭川本流で大沢出合付近まで, 丸石沢や針ノ木谷では標高 $1,900 \mathrm{~m}$ 付近まで，北葛 沢では標高 $1,600 \mathrm{~m}$ までそれぞれ認められる。

II 期 : 篭川本流の標高 $2,080 \mathrm{~m}$ 付近のノドより上 流側に発達する氷食壁, 針ノ木谷 (L 沢)の標高 2,050 $\mathrm{m}$ 付近のモレーン状地形とそれより上流側の氷食 壁, 大沢 $\mathrm{G}$ 沢の標高 $2,090 \mathrm{~m}$ のモレーン状地形, 丸 石沢の標高 2,100 m のモレーン状地形などが形成さ れたものと考穴られる。

III 期: 標高約 2,300 m のマヤクボ沢モレーン, 大 沢 F 沢の標高約 2,430 m のモレーン状地形, 針ノ木 谷 ( $\mathrm{L}$ 沢)の標高約 $2,170 \mathrm{~m}$ のラテラルモレーンなど が形成されたものと判断した。またここの前進期に 形成された氷食壁は, ほぼカール状地形を形作って いる。 


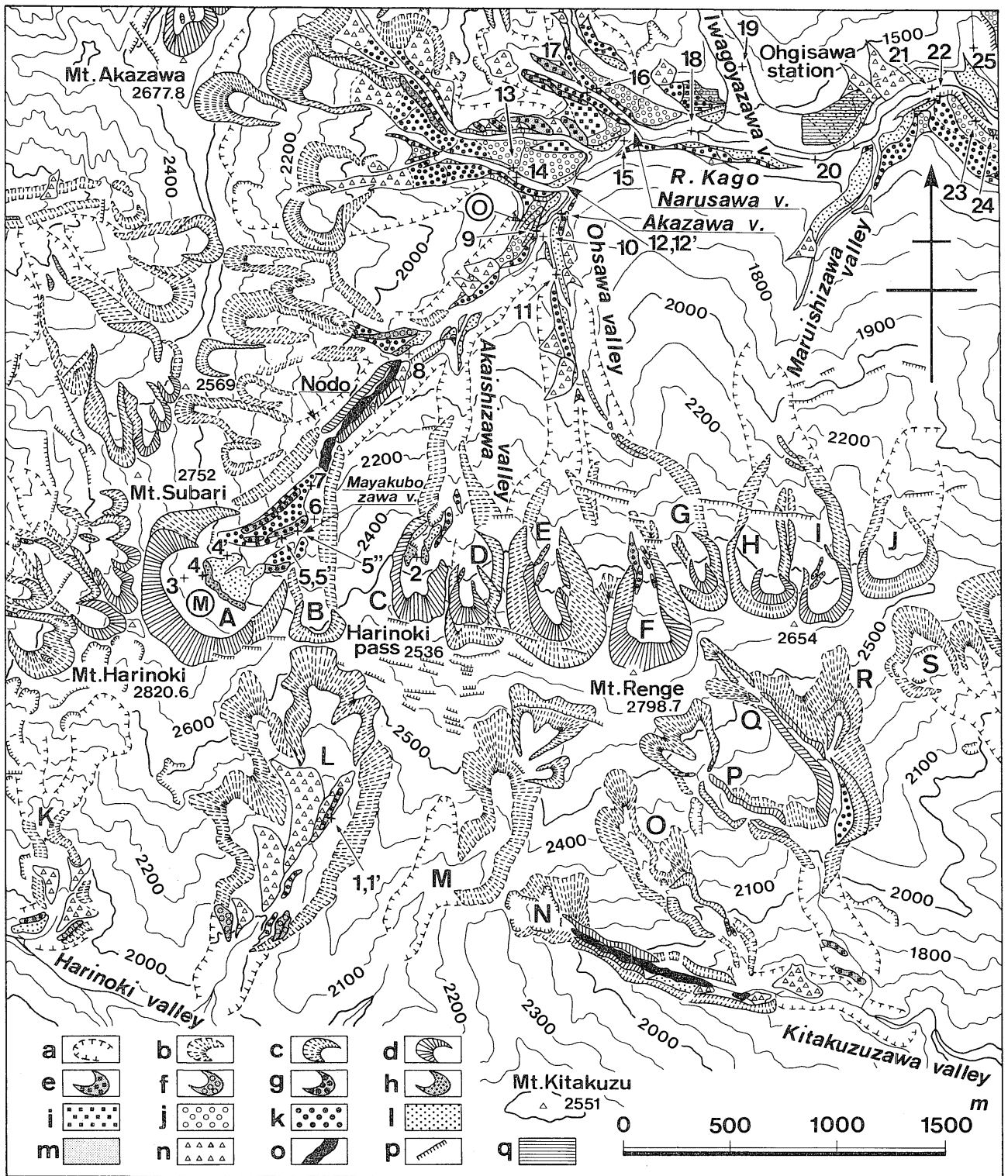

第 3 図針ノ木岳・蓮華岳周辺の水河地形分布図

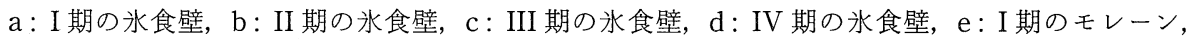
$\mathrm{f}$ ：II 期のモレーン，g：III 期のモレーン，h：IV 期のモレーン，i：I 期のアウトウォッシュ段丘 と河成段丘，j：II 期のアウトウォッシュ段丘と河成段丘，k：III 期のアウトウォッシュ段丘と河 成段丘， 1: IV 期のアウトウォッシュ段丘と河成段丘， $\mathrm{m}$ : 沖積段丘と土石流扇状地， $\mathrm{n}$ : 崖錐, $\mathrm{o}:$ 越年性雪渓 (1978.9.18 現在), $\mathrm{p}$ : 断層を含む小崖地形, $\mathrm{q}$ ：人工改変地 図中の $\mathrm{A} \sim \mathrm{S}$ は支流の沢名. 1 25 は主な観察地点. (M)：マヤクボ, $(\mathrm{O})$ ：大沢小屋

IV 期：マヤクボカール底端，標高約 2,530 m のマ ヤクボモレーン，赤石沢 C 沢の標高約 $2,460 \mathrm{~m}$ の カール底のモレーン，大沢 $\mathrm{E}$ 沢の標高約 $2,410 \mathrm{~m}$ の
モレーン状地形，丸石沢 I 沢の標高約 2,500 m のモ レーン状地形などが形成されたものと考学られる。 この前進期の氷食壁は，局所的な雪崩涵養型の氷河 
が分布していた地域を除き，新鮮なカール壁として 認められるが，南側斜面には分布しない。またその カール壁は, III 期のカール壁内に形成されている場 合が一般的である。

次に,このように 4 回の前進期に分けたそれぞれ の水河地形の詳しい記載を行う。

\section{3. 北側斜面の水河地形}

1）篭川本流マヤクボ沢の氷河地形

篭川本流は最上流部で, 針ノ木峠へ至る針ノ木沢 (B 沢)とマヤクボ沢 (A 沢) とに分岐する。マヤク ボ沢谷頭部には，マヤクボ（厩窪）とよばれている カール状地形が発達し，針ノ木沢と合流するあたり から下流側には，U字状の谷地形が発達している。 今村 (1940) は, マヤクボの地形をカールと普通の 谷との中間的なものとし，その付近でのモレーンの 分布は認めていない。また小林 (1964) は, これを 弱い氷食作用によって形成された雪食カールと考光 た（平林，1984）。五百沢（1979）は，篭川本流上流 部を開析された $U$ 字谷と考え, マヤクボの下部の地 形をU字谷谷頭に打ける氷食谷源頭壁（trough headwall, Trogschluß) と判断した。一方, 平林 （1984）もマヤクボの地形については五百沢（1979） とほぼ同じに考光，マヤクボのカールと呼んだ。 マヤクボのカール状地形は, 標高約 $2,540 \mathrm{~m}$ に カール底状地をもつ長さ $430 \mathrm{~m}$, 幅 $630 \mathrm{~m}$ の幅広な 半椀状を呈する。カール壁状斜面の比高は 150 ～ 280 $\mathrm{m}$, カール底状地は, カール状地形が小規模なわりに は平坦性に富んで打り，この平坦地や山地にはプロ テーラスランパートや崖錐が形成されている。カー ル底状地開口端には, カール底状地との比高約 2.5 $\mathrm{m}$, 幅 20〜30 m のターミナルモレーン状のリッジが 約 $250 \mathrm{~m}$ 連続して発達する。このリッジを構成する 堆積物は, チングルマなどの草本帯やハイマッ帯に 覆われているため明らかでないが，地表の Loc. 4 で は砶径最大 $4 \mathrm{~m}$, 平均 $21 \mathrm{~cm}$ の火山角䃯岩と若干の 流紋岩の角礫が分布する。この角礫を充填するマト
リックスは砂であるが，充填しない場合も少なくな い。このように, 礫径が比較的大きく, マトリック スがそしいこと, カール底状地開口端のターミナル モレーン状地形の上部を構成していることから，こ の上部の角碩層は ablation till として形成されたも のと判断できる。

このリッジの下流側は氷食谷源頭壁状の形態を示 すが，リッジと連続して，傾斜してはいるものの平 滑な堆積地形面が発達する。この地形面を構成する 礫層は, 露頭の位置から判断して $3 \mathrm{~m}$ 以上の層厚を もつ。構成礫の平均碟径や碟種は, Loc. $4^{\prime}$ に招いて 上記のリッジ頂部のものとほぼ同じであり，後述す る粒度分析結果からも水河に起因した堆積物である ことがわかった。以上の事実から，マヤクボでは明 らかに氷河が形成されていたものと考光られ, 上記 のリッジはカール底のターミナルモレーン, そして そのリッジと連続する下流側の堆積地形はアウト ウォッシュ段丘と判断できる。そこで，このカール 状地形をマヤクボカール, カール底のターミナルモ レーンをマヤクボカール底モレーンとそれぞれ呼ぶ ことにする。

マヤクボカールより下流側の, マヤクボ沢両岸, 特 に左岸側の標高約 $2,300 \mathrm{~m}$ には, ハイマッやダケカ ンバに覆われたラテラルモレーンないしターミナル モレーン状の 2 本のリッジ地形が発達する。これら のリッジ頂部と河床との比高は約 $30 \mathrm{~m}$, また前述し たアウトウォッシュ段丘とは最大約 $25 \mathrm{~m}$ の比高を もち，両者は連続しない(第 4 図)。このリッジを構 成する灰色を帯びた堆積物は，基盤の褐色を帯びた 風化層とは不整合面で接し, 約 $20 \mathrm{~m}$ の層厚で堆積 する。この堆積物の沢沿いの Loc. 5 には, 灰色の粘 土とシルトをマトリックスとする火山角䃯岩と若干 の流紋岩からなる角礫層が分布する。この角礫層は, 無淘汰, 無層理の層相を示し, 固結度が非常に高く, 明らかにティルと判断することができる。特にLoc. 5 の位置や上記の層相から，このティルの部分はグ 


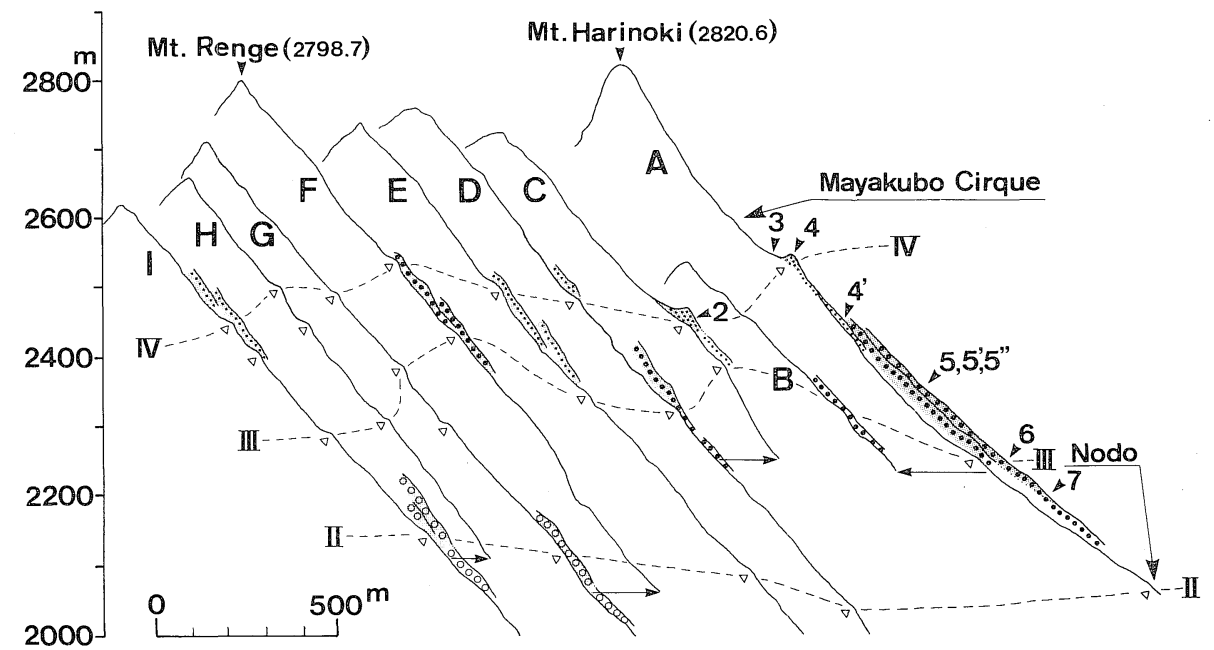

第 4 図 北側斜面（篭川上流部）に打ける河川及び氷河堆積地形等投影断面図 凡例は第 3 図に同じ。図中の A I は沢名，数字は観察地点番号で位置は第 3 図を参照。 வは主な遷急点を示し, IV, III, II の破線はそれらの氷河前進期における氷食谷底末端位置に相当す る。

ランドモレーンのティルと考学られる。またその上 部には，このティルと比べ，粘土質なマトリックス には欠けるものの，㴗济それと同様の角碩層がリッ ジ頂部まで連続する。したがって，これらのリッジ を構成する堆積物はティルと考㝋られ，第 3 図に示 したリッジの形状から，ラテラルモレーンあるいは ターミナルモレーンとして形成されたものと判断で きる。そこでこれらのモレーンをマヤクボ沢モレー ンと呼ぶことにする。

一方, マヤクボ沢モレーン周辺には, リッジ頂部 から連続する比較的平滑な堆積地形が発達し（第 4 図), 後述するLoc. 7 の堆積物の分析結果などから, アウトウォッシュ段丘と考学た。おた，マヤクボ沢 付近の右岸側斜面では一部基盤が認められ, 水河擦 痕（glacial striae）の発達する羊群岩が分布する。

マヤクボ沢モレーンの周囲には, マヤクボカール のカール壁よりもいくぶん開析された氷河研磨面状 の水食壁と考学られる斜面が発達する。この水食壁 は, カール壁の形態から復元されるカール氷河の水 舌によって形成されたと考学るには，位置的により
奥に発達する。一方，この水食壁が下流側で消滅す る位置には，マヤクボ沢モレーンが分布する。また この氷食壁は, マヤクボカールのカール壁よりもい くぶん開析が進んで和り, 後述する下流側の氷食壁 とは位置的に連続しない。以上の事実から, この水 食壁はマヤクボ沢モレーン形成期 (III 期) に形成さ れたものと判断できる。

2) . 篭川本流, 針ノ木雪渓付近の氷河地形

篭川本流，1,900 2,150 m の狭窄部には越年性雪 渓である針ノ木雪渓が発達し, その上部標高約 2,050 $\mathrm{m}$ 付近は通称ノドと呼ばれている谷幅 50 - $100 \mathrm{~m}$ のとりわけ狭い部分となっている。この狭窄部は, 篭 川本流の遷急点にもなっている。ノ゙の上流側には, 扇型状あるいは袋状の谷幅の広がった地形が発達す る。この地形をつくる谷壁は, ガリーや雪崩によっ て開析されてはいるが, その谷壁斜面にはU 字谷谷 壁上端と肩地形の組合わさった地形も残されてい る。U字谷谷壁上端はガリーなどによって断続して はいるが，比較的良好につながる。U 字谷谷壁上端 の下部の斜面は, 植生に覆われてはいるが, 氷河研 
磨面状の切断山脚として発達し, 第 3 図に示される ように下流側のノド付近で閉塞するように分布して いることがわかる。したがって，上記の谷壁は氷食 壁と考兄られ，この八ド付近より上流側飞水河が形 成されていた可能性が高い。しかしノド付近に揖い て,モレーンなどの堆積地形は発見されていない。ま たこの氷食壁は, 前述したマヤクボ沢モレーン形成 期（III 期）に形成された氷食壁とは位置的に連続せ ず, 開析の度合もちがうことから, マヤクボ沢モレー ン形成期よりも以前（II 期）に氷食作用をうけたも のと推定される。

ノドから下流側に至る針ノ木雪溪両岸には，急傾 斜な水河研磨面状の谷壁が連続して発達する。特に 雪溪との比高約 $50 \mathrm{~m}$ の高度までは, $60^{\circ}$ 以上の傾斜 をもつ裸岩壁や植物の被覆度の低い比較的新鮮な谷 壁(IV 期)が分布し，その上端には U 字谷谷壁上端 が形成されている。このU 字谷谷壁上端の位置から さらに上方に約 $50 \mathrm{~m}$, 上記の下側の斜面よりやや 傾斜の緩い谷壁 (I 期) がつづくが，その上端にも U 字谷谷壁上端の発達が認められる。この上側斜面は, 下側斜面に比べ，開析されているというょりもむし ろ植物の被覆度が高く, その斜面形はソリフラク ションを受けた周水河斜面に近い。また両斜面とも, 水平方向にスムースな連続性を示し, 氷食壁として の特徵を有する。U 字谷谷壁上端は下側斜面(IV 期) のものが Loc. 8 付近まで連続し，上側斜面 (I 期)の ものは, 標高 $1,700 \mathrm{~m}$ 付近の大沢出合まで断続的で はあるがつながっている。またLoc. 8 の右岸側で は, 斜面の位置や開析の程度, U 字谷谷壁上端の高 度から判断して，前述した両斜面の中間型の谷壁 (III 期)が認められる。したがってこの付近では，少 なくとも異なった 3 回の氷河前進期 (I 期, III 期, IV 期）に形成された谷壁が分布していることになる。

越年性雪渓の分布する地域は, 氷期に招いて子水 河が発達しやすかったことは従来より知られ（五百 沢，1979），針ノ木雪溪付近でも，水期に氷河が発達
しやすい条件が整っていたと想定される。針ノ木雪 渓は，雪崩によって涵養された雪渓，すなわち下位 万年雪（今西，1929；五百沢，1979）に相当するの で，この付近では，氷期に扣いても主に雪崩によっ て涵養された氷河が形成されていたものと推定され る。また前述したような谷壁の特徴から判断して, 前 述した針ノ木雪溪付近の谷壁の下側斜面を形成した 水河前進期は，比較的新しい時期（IV 期）ではなか ろらか。そうすると，上流側のマヤクボでも比較的 新しい時期 (IV 期) に氷河が発達していたことが 判っているので, 同じ流域の上流側と下流側との 2 ケ所に，分断したかたちで氷河が発達していた可能 性が高い。この場合, 上流側の氷河は主に気候的条 件下で，下流側の水河は主に地形的（位置的）条件 下でそれぞれ形成されたものと考觉られる。このよ らな例は, 北葛沢に和いても認められる。李た Loc. 8 の左岸側には, モレーンと考觉られるリッジやア ウトウォッシュ段丘と考光られる堆積地形が分布す る。露頭がないためこれらの堆積物については明ら かではないが, 地形の高度と位置, 植生の状態, 水 食壁との位置関係から，第 3 図に示す分布状態と考 壳た。

3）篭川本流, 大沢出合付近の氷河地形

大沢出合付近の本流左岸側, 標高 1,650 1,700 m には, モレーンの可能性がある堆積物として平林 (1984)が図示した大沢小屋付近の段丘状の堆積地形 が発達する。堆積地形面は第 3 図や第 5 図に示した 通り, Loc. 9 付近ではいくつかの面に区分すること ができる。簡易測量の結果から, 堆積面では比高最 大 $3 \mathrm{~m}$ のラテラルモレーンあるいはターミナルモ レーン状のリッジが 2 列, 場所によっては 3 列汪ど 発達している。堆積物は層厚 $25 \mathrm{~m}$ 以上, 火山角䃯 岩, 流紋岩, 安山岩, 花崗岩からなる䃯径最大 $2 \mathrm{~m}$,

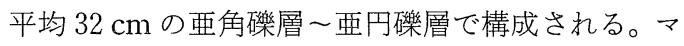
トリックスはシルトや砂であるが, 部分的に灰色粘 土が多く含まれるところも認めら机る。微弱な層理 


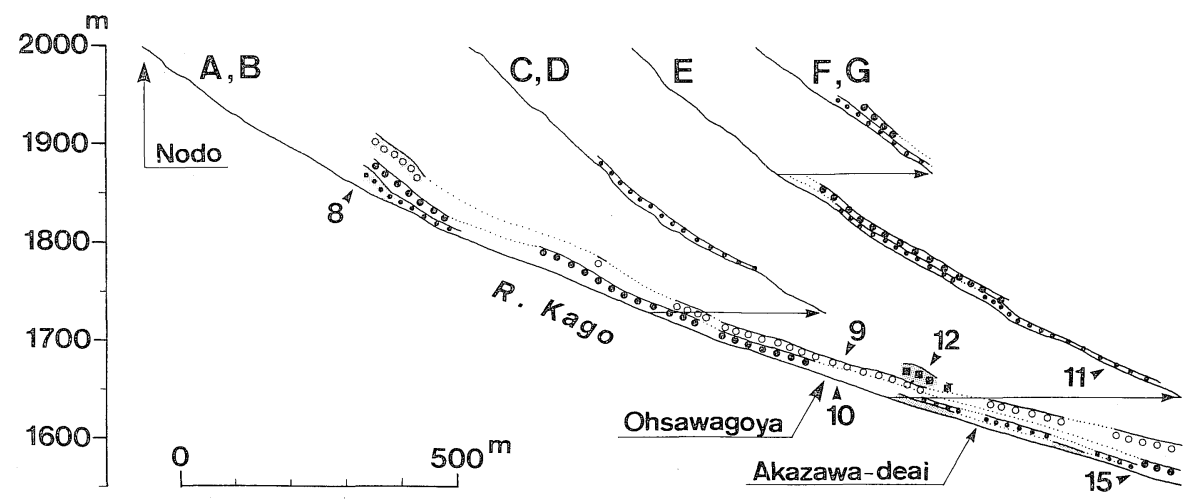

第 5 図 北側斜面（篭川中流部）に抢ける河川及び氷河堆積地形等投影断面図 凡例は第 3 図に同じ。図中の数字は観察地点番号で，位置は第 3 図を参照。

やインブリケーションも認められ，少なからず水流 の影響を受けていることが判る。このような層相と， 後述する堆積物の分析結果とから，この堆積物は ティルといらよりはむしろアウトウォッシュと考党 た方がよさそらである。一方，この堆積物と背後の 氷食壁との位置関係をみると，この堆積地形をモ レーンと考えるには，堆積面の位置が低すぎる。し たがってこの堆積物の形成期は，背後の氷食壁の形 成期 (I 期)よりは新しくなる。また礫層を覆らテフ ラ層も薄く, テフラは二次的な堆積相を示し，姶良 Tn 火山灰 (AT：姶良カルデラ起源) 特有の火山ガ ラス片（町田・新井，1976）も萎とんど認められな かった。しかしこの堆積地形が，氷食壁を形成しな いよらな微弱な水河によって，比較的新しい時期に 形成されたモレーンである可能性も残る。

大沢出合の本流右岸側, 標高約 $1,670 \mathrm{~m}$ の Loc. 12 には，河床からの比高約 $30 \mathrm{~m}$ の開析された段丘状 ないしはラテラルモレーン状の堆積地形が分布す る。前述した左岸側の段丘状地形よりも約 $10 \mathrm{~m}$ 高 い(第 5 図)。砂防堰堤工事のために形成された露頭 では，花崗岩の風化基盤岩を覆い，層厚 $2 \sim 8 \mathrm{~m}$ ，碟 径 1〜13 cm の角碟層が堆積している。この角礫層 を不整合に覆って，層厚 $6 \mathrm{~m}$ 以上，砂やシルトをマ トリックスとし，最大礫径 $140 \mathrm{~cm}$, 平均礫径 $38 \mathrm{~cm}$

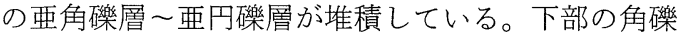
層の形成要因については判らないが，上部の亜角磻 層〜亜円碟層については，層理もほとんど発達しな いことや，前述した氷食壁との位置関係から，ティ ルの可能性が高い。しかしその地形はほとんど開析 されていることから，今のところモレーンであると は断定できない。

4）赤石沢及びその周辺の氷河地形

赤石沢右俣 (C 沢) 谷頭部には, 形の整ったカール 状地形が発達し，標高約 2,450 m のカール底状地に は，凹地や平坦地が広がり，その開口端にはターミ ナルモレーン状の小丘も存在する。カール底状地の Loc. 2 では，安山岩ないしは流紋岩の風化基盤岩を 覆って，3〜 $5 \mathrm{~m}$ の層厚をもつ無淘汰，無層理の角砅 層が堆積している。マトリックスは後述する通り, 粘 土やシルトが多く，ティルのものと考光てさしつか えない。また最も新しい氷河前進期に形成されたと 考えられるカール壁状斜面は，このモレーン状の小 丘付近で谷を閉塞するように発達する。またこのモ レーン状の小丘に連続して，アウトウォッシュ段丘 と考它られる堆積地形が約 $120 \mathrm{~m}$ 発達する。した がって，この赤石沢谷頭部に氷河が分布していたこ とは明らかである。

このような地形は, 第 3 図に示した通り, 赤石沢 
左俣 (D 沢), 大沢 $(E \sim G$ 沢), 丸石沢 $(H \sim I$ 沢 $)$ な ぞにも発達し, カール壁を含む水食壁の下流側の閉 塞位置には，モレーンと推定される地形が分布する 場合が多い。第 4 図に示す河川の縦断形を見ると，モ レーンの分布位置が河川の遷急点の位置と一致して いる場合が多く認められる。すなわちこれらの遷急 点の位置は, 後述する水河前進期の水河末端高度と 一致することになる。カール地形の下流側は氷食谷 源頭壁状の急斜面になっている。この付近の谷壁は, 傾斜が急なことから開析されてはいるが，氷食壁と 考えられるスムースな谷壁とその上端にU 字谷谷 壁上端が認められる。これらの沢のなかで, 赤石沢 の最も古い氷河前進期 (I 期) 飞形成されたと考㝋ら れる水食壁やU 字谷谷壁上端は, 篦川本流のそれら とつながっている。

\section{5）大沢出合より下流側の地形}

大沢出合より下流側の赤沢, 鳴沢, 岩小屋沢出合 の本流左岸側には, 層厚 $20 \mathrm{~m}$ 以上の堆積段丘状の 地形が広く発達する。これらの堆積物の地形面は各 沢上流部に高度を上げ，また後述する碟種分析の結 果から, 堆積物の給源を各沢上流部に求められるこ とは明らかである。平林 (1984) は, これらの堆積 物がティルとして形成された可能性があると考兄， また最近の雪や水の影響で氷食作用の有無は判らな いとしながらも，赤沢や岩小屋沢の谷頭部にカール 状地形を認めている。赤沢, 鳴沢, 岩小屋沢の各上 流部には，空中写真判読だけからでも，承食地形の 痕跡を認めることがでさる。しかし，これらの沢は いずれも開析が著しく, 現在でも雪崩や土石流の発 生が認められ, 特に岩小屋沢谷底には, 現成の堆積 地形が広く分布する。赤沢上流部には，平林(1984) の言う通り，複合したカール状地形が分布している が，平坦なカール底状地は認められない。このよう な地形は, その谷の縦断形がカール底の端に相当す る位置で顕著な傾斜変換点をもたないことから，い わゆる谷頭カール (Quelltrichterkar) と呼ばれてい
るものに相当する。Loc. 13 や Loc. 16 の堆積物は, 層理やインブリケーションも認められること, その 地形面が比較的平坦な段丘面状を呈していること， また後述する粒度分析の結果から，ティルや河成段 丘碩層よりむしろアウトウォッシュと考光たほらが よさそうである。また，露頭も分布していないこと から詳しい調査は行っていないが，赤沢や鳴沢の出 ロには，モレーンと考光ら机る地形も認められる。

扇沢出合の本流右岸, 標高 1,300 1,400 m の Locs. 22, 23, 24 付近にも, 堆積段丘状の地形が広く 発達する。この地形を五百沢（1979）は, 河岸段丘 状のモレーンと判断し, 町田（1979）は扇沢からの 土石流堆積物と判断した。また平林（1984）は，モ レーンと土石流堆積物との両者の可能性を指摘して いる。地形面は，高度のちがいから，この付近では 3 面程度に区分できる。最も高位の面（II 期の段丘 面）が Loc. 23, 中位の面（III 期の段丘面）が Loc. 22 , 低位の面（IV 期の段丘面）が Loc. 24 に相当す る。高位の地形面は, 段丘状というょりはターミナ ルモレーン状のリッジ地形を呈し, 南方向と東方向 に傾斜している。この堆積物は, 最大磁径約 $4 \mathrm{~m}$, 平 均砂径約 $30 \mathrm{~cm}$ の亜円碟層〜亜角碟層で構成され る。亦た後述する礫種分析結果からも, 扇沢から砂 礫が供給されたことは明らかである。しかしこの付 近は人工の手も若干加わり, また扇谷流域も未調査 なため，その成因については今後検討を要する。一 方, 中位や低位の面を構成する Loc. 22 や Loc. 24 の 礫層は本流系のもので, 地形面も比較的平坦で, 段 丘としての特徵を備えている。

\section{4. 南側斜面の水河地形}

1）針ノ木谷の水河地形

針ノ木谷 (L 沢) は, 五百沢 (1979) が空中写真判 読から認めたように, 平面的には馬蹄形状を呈し, 谷 の横断形はU 字状を呈する谷頭カール状の地形々 なっている。谷の開口端は切断山脚が閉塞する位置 に相当し，そこでは峡谷が形成されている。この峡 


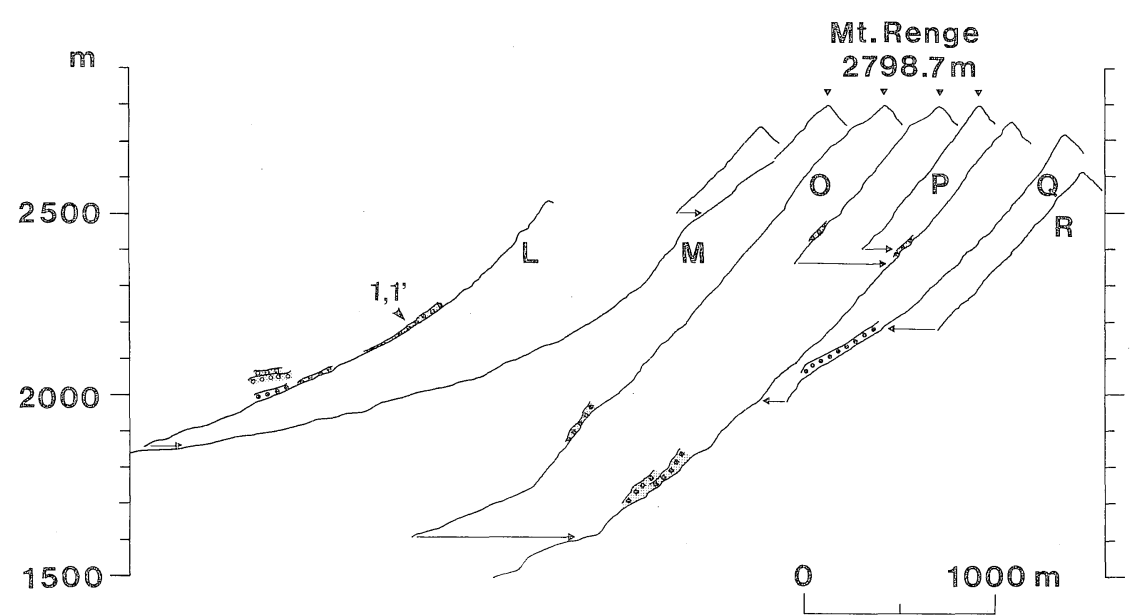

第 6 図 南側斜面（針ノ木谷・北葛谷）に抢ける河川及び氷河堆積地形等投影断面図 凡例は第 3 図に同じ。図中の数字は観察地点番号で，位置は第 3 図を参照。

谷は，一般的な河川の開析を受けて形成されたもの である。開析は，標高 $2,000 \mathrm{~m}$ まで，すなわち谷頭 カール底状地の下流部 $1 / 4$ まで進んでいる。その標 高 2,000 $\mathrm{m}$ より上流部の谷底は, 比較的平坦ないし 緩傾斜で, 後述するU字谷谷壁上端の部分を除いて 添とんぞ傾斜変換部がないま李に谷壁につながる (第 6 図)。崖錐の発達も認められるが，それらは植 生比覆われて扮り，安定している。

前述した谷頭カール状地形の谷壁斜面には，氷河 研磨面状の切断山脚が発達し, その上端には $\mathrm{U}$ 字谷 谷壁上端も認められる。この切断山脚やU 字谷谷壁 上端は, 谷の 3 ケ所, すなわち谷底での標高約 2,250 $\mathrm{m}, 2,000 \mathrm{~m}, 1,900 \mathrm{~m}$ 付近で, 谷を閉塞するように発 達する。上流側の切断山脚は下流側の切断山脚とは 位置的に連続しない。これらの切断山脚やU字谷谷 壁上端は，過去に崩壞や雪崩によって部分的に開析 されて抢り，切断山脚の下部から谷底に到る地域に は崖錐の発達が認められる。しかしそれらは，植生 も密で，現在では比較的安定している。また標高 1,900 m から下流側では, 氷河研磨面状の切断山脚 は認められない。

標高約 $2,170 \mathrm{~m}$ の谷底左岸側には, 比高約 $15 \mathrm{~m}$,
長さ約 $220 \mathrm{~m}$ の細長いラテラルモレーン状の小丘 地形が発達する。Loc. 1 の露頭では, 層厚 $13 \mathrm{~m}$ 以上 の磁層が堆積し，層相から下部層と上部層に区分で きる。下部層は，層厚約 $20 \mathrm{~cm}$ のシルト層を挟み最 大礫径約 $40 \mathrm{~cm}$, 平均礫径 $11 \mathrm{~cm}$ の比較的小さな鿬 で構成される層厚 $5 \mathrm{~m}$ 以上の角䃋層であり，上部層 は, シルトや砂をマトリックスとする最大礫径約 2 $\mathrm{m}$, 平均碟径 $30 \mathrm{~cm}$ の比較的大きな礫で構成される 層厚約 $8 \mathrm{~m}$ の角碟層からなる。両者は不整合関係と いらょりも，漸移している。層理は，顕著ではない が，下部層の方で部分的に認められる。またこの小 丘地形は，前述した切断山脚のなかで最上流部の山 脚が閉塞する付近に位置し，その山脚と小丘地形と は位置的につながる。さらに後述の石英砂粒の観察 結果からも，この小丘地形がモレーンである可能性 が認められた。以上に述べた地形や位置, 堆積物の 層相などから，この小丘地形をモレーン，特にLoc. 1 付近の地形はラテラルモレーンと判断した。

このモレーンの下流側には, 断片的ではあるが堆 積段丘が分布する。この段丘は，モレーンと高度的 に連続するので，アウトウォッシュ段丘と考光られ る。前述した峡谷がはじする標高 $2,000 \mathrm{~m}$ 付近で，こ 
のアウトウォッシュは，亜角礫層〜亜円礫層に変化 する。一方, その付近の両岸の斜面上部, 標高約 2,050 $\mathrm{m}$ には，小丘地形が開析されたよらな比較的平坦な 堆積地形が谷壁に付着するように分布する。露頭が ないためこの堆積物については明らかではない。し かしこの地形は，両岸とも前述した切断山脚の閉塞 する 3 ケ所のなかで, 中流部の閉塞地点に位置し，モ レーンの可能性がある。またこの堆積地形は, 前述 した上流部のラテラルモレーン状のモレーンとは高 度的に連続しない(第 6 図)。

以上述べたように，針ノ木谷 (L沢)に和いても， 過去に氷河が発達していたことは明らかで，モレー ンと考えられる 2 ケ所の地形は，いずれも切断山脚 やU字谷谷壁上端が閉塞する位置に分布する。ただ し, 最も下流側の切断山脚やU字谷谷壁上端が閉塞 する位置には，モレーンは発見されていない。

2）針ノ木谷以外の谷の水河地形

針ノ木谷 ( $\mathrm{L}$ 沢)以外の谷は調査が困難なため, 氷 河地形の分布は空中写真判読によった。これらの谷 では，針ノ木谷の場合と同様，カール状地形よりも むしろ谷頭カール状の水食谷や雪崩涵養型の水河に よって形成された谷幅の狭いU字状の氷食谷が発 達している。しかもそれらは開析が進んでいる場合 が多く, 北側斜面谷頭部の水河地形のように, 比較 的新しい時期に形成されたものは居とんど認められ ない。

蓮華岳南西の $\mathrm{M}$ 沢に打ける水河地形の分布は, 湴 ぼ針ノ木谷の場合と同じであるが，モレーン状の地 形は認められない。北葛岳北東の水河地形の分布は 針ノ木雪渓付近のものと酷似する。蓮華岳南東の $\mathrm{P}$ 沢や S 沢の谷頭部には, 南斜面では例外的にカール 状地形が発達するが, いずれも開析が進んで扣り, 平 坦なカール底状地は認められない。Q 沢中流部では, 水河研磨面状の比較的古い斜面之段丘状の地形が良 く保存されている。

\section{5. 堆積物の分析結果}

1）䃯種組成，碟径及び円磨度

測定は，伊藤・正木（1987）の方法に従った。す なわち堆積物の露頭において，その堆積物の特徴を 最す良く表わしている地点を吟味し，その付近に 3 $\mathrm{m} \times 3 \mathrm{~m}$ のメッシュをかけ，最も大きな礫から50個 を選び行った。䃯種組成は，䃯の個数の割合ではな く，䃯の中軸の值をそれぞれの礫種のものについて 合計したものを割合で表示した。碟径の值は，上記 50 個の䃯の長軸, 中軸, 短軸それぞれの平均値で示 してある。円磨度の測定はクルンバインのチャート を使用し，50 個の䃊の平均值を算出した。これらの 結果を第 7 図に示す。測定地点の位置は第 3 図に示 す通りであるが，現河床堆積物と比較するため，下 流側の Locs. 26〜30 の結果を付け加壳た。 地形や層相からティルと判断したLocs. 1, 2, 4, 5 は, プロテーラスランパートの Loc. 3 より砂径は小 さく, 円磨度が高い。これは, プロテーラスランパー トが雪田の上を滑落して形成されたのに対し，ティ ルが氷河底で融水水の影響を受けながら摩耗されて 形成されたといら差が表われたものと考光られる。 またLoc. 4 のターミナルモレーンのティルは, Loc. 5 のグランドモレーンのティルに比べ碟径が大き く, 円磨度も低いという当然の結果となった。Loc. 5 の円磨度のところの $5^{\prime}$ は近接するラテラルモ レーンのティルの測定值であるが，ラテラルモレー ソよりグランドモレーンの方が円磨度が高く，グラ ンドモレーンが水河底に执いてより円磨されたこと が判る。

アウトウォッシュの Locs. 7, 9 が, 上流部のティ ルよりも礫径が大きい事実は，両者の位置関係を考 光ると矛盾した結果となっている。しかし，ティル とアウトウォッシュとの間に分布する谷壁やその間 の支流から碟の供給があったことも当然考光られ る。またそれらの付近の現河床の Locs. 6, 8, 10 など は, 上記のアウトウォッシュやティルなどに比べる 


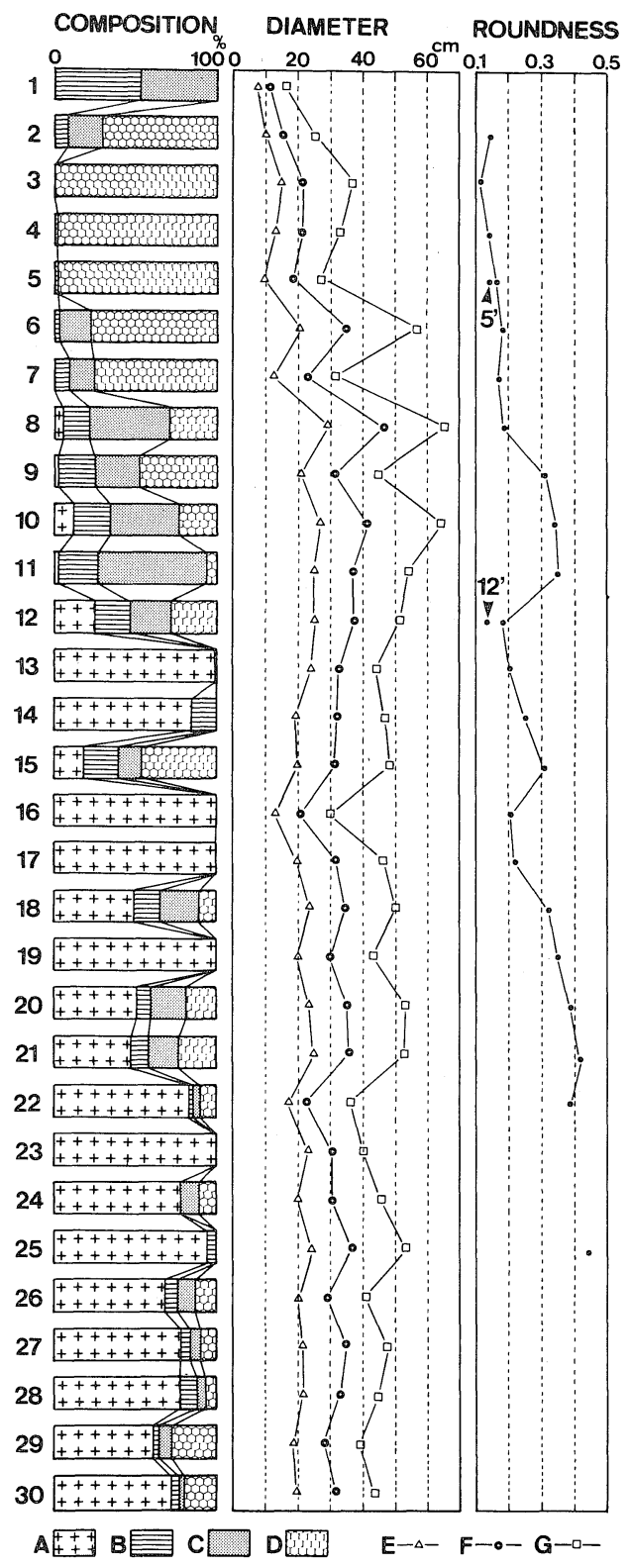

と礫径ははるかに大きく, 円磨度も高い結果となっ ている。

大沢小屋付近の Loc. 9 の段丘状堆積物は，近接す る現河床の Loc. 10 Loc. 11 に比べると䃯径は小 さく, 円磨度もやや低い結果となって抢り，ティル と現河床との中間的な值となっている。Loc. 9 の対 岸の Loc. 12 はティルの可能性が指摘できた堆積物
第 7 図碟種組成・碟径・円磨測定結果

【䃯種組成】A：花崗岩, B：流紋岩, C： 安山岩, D : 火山角砅岩～凝灭角砅岩

【碩径測定結果】 $\mathrm{E}$ : 短軸平均値, $\mathrm{F}$ : 中軸 平均値, $\mathrm{G}$ : 長軸平均值

【円磨度測定結果】測定はクルンバインの チャートによる。(5') : Loc. 5 付近のラテ ルモレーン(標高 $2,350 \mathrm{~m}$ ), (12') : Loc. 12 付近の崖錐性堆積物

【地点名とその標高】1：針ノ木谷ラテラル モレーン $(2,140), 2$ : 赤石沢右俣カール底 モレーン $(2,460), 3$ : マヤクボカール底プ ロテーラスランパート $(2,560), 4:$ マヤク ボモレーン $(2,540), 5$ : マヤクボ沢モレー ン（グランドモレーン）(2,345)，6：マヤ クボ沢出合現河床 $(2,240), 7$ : 本流上流部 左岸アウトウォッシュ段丘 $(2,180), 8$ : 本 流現河床 $(1,850), 9$ : 本流中流部左岸アウ トウォッシュ段丘(大沢小屋付近) $(1,670)$, 10 : 本流現河床 $(1,660), 11$ : 大沢現河床 $(1,690), 12$ : 本流右岸最低位モレーン $(1,665), 13$ : 赤沢段丘 $(1,700), 14$ : 赤沢 現河床 $(1,680), 15$ : 本流現河床 $(1,570)$, 16: 鳴沢段丘 $(1,660), 17$ : 鳴沢現河床 $(1,650), 18$ : 本流現河床 $(1,505), 19$ : 岩 小屋沢現河床 $(1,555), 20$ : 本流現河床 $(1,420), 21$ : 本流現河床 $(1,350), 22$ : 本 流右岸段丘 $(1,365), 23$ : 本流右岸段丘 $(1,330) ， 24$ : 本流右岸段丘 $(1,280), 25$ : 扇沢現河床 (1,340), 26: 本流現河㦿 $(1,240), 27$ : 本流現河床 $(1,120), 28$ : 本 流現河床 $(1,025), 29$ : 本流現河床 (940), 30: 本流現河床 (840) Loc. 1 25 の位 置は 3 眓を参照。

であるが，現河床と比べ䃯径にはとれほど差異は認 められない。しかし，円磨度は非常に低い值が出て 扣り，この結果については解釈し難いが，ティルの Loc. 2, 4, 5, 5' の円磨度の值とほぼー致している。た だしこの值は，その付近の崖錐性堆積物の円磨度の $12^{\prime}$ よりは高い。

Loc. 13 と Loc. 14, Loc. 16 と Loc. 17 の関係は, 
赤沢と鳴沢に扮ける段丘䃯層と現河床の磕との関係 である。䃯種組成については，段丘・現河床ともに 同じであるが，礫径については同じか，やや現河床 の方が大きい。円磨度についても，現河床の方が高 くなる傾向が認められる。一方, Locs. 22, 23, 24 は 扇沢出合付近の本流右岸の段丘礫層に相当する。 Loc. 23 の砂礫は, 礫種組成からみて明らかに扇沢か ら供給されたものである。その礫径は, Loc. 23 の扇 沢現河床碟よりもはるかに小さい。したがって段丘 䃯層と現河床䃯との特徵のちがいから, これらの地 点の段丘碩層は，現在の河床䃯とは異なった礫の運 搬作用によってもたらされたことが推察される。

一方, 本流の現河床については, 上流部より Locs. $6,8,10,15,18,20,21,26 \sim 30$ で測定したが，下流部 ほど花崗岩礫が多く含まれ, 礫径は小さく, 円磨度 は高くなる傾向が認められた。

2）マトリックスの粒度組成

礫の測定を行ったそれぞれの地点で，最も粘土質 なマトリックスを採取し, JIS A1204-70 に基づく粒 度分析（土質工学会，1983）を行い，結果を第 1 表 に示した。粘土, シルト, 砂の粒度区分は JIS に従 い，それぞれ $<0.005 \mathrm{~mm}, 0.005 \sim 0.074 \mathrm{~mm}, 0.074$ 〜2.000 mm とした。小疇潘か(1974)は Flint (1971) の結果を考慮し,ティルの判断基準として，1）粘土 $10 \%$ 以上，2）粘土十シルトが $40 \%$ 以上，3）堆積 物の層相がコンパクトなもの，の 3 つの基準を設定 した。小疇はか（1974）は，粘土，シルト，砂の粒 度区分として, $<0.004 \mathrm{~mm}, 0.004 \sim 0.062 \mathrm{~mm}, 0.062$ 〜2.000 mm を採用しているため, 実際の粒度分布は 多少異なるが，本研究でも小疇法か（1974）の基準 を用いてティルの認定を行った。

粒度分析試料のなかで, 地形や堆積物の層相から ティルと判断したものは Locs. 1, 2, 5, 5' $5^{\prime \prime}$ であり, アウトウォッシュと判断したものは Locs. $4^{\prime}, 7,9$, 13, 16, 22 で, 残りの Locs. 10, 21 は現河床堆積物で ある。
第 1 表 粒度分析結果

\begin{tabular}{c|r|r|r}
\hline \hline Loc. & $\begin{array}{c}\text { Clay } \\
(\%)\end{array}$ & $\begin{array}{c}\text { Silt } \\
(\%)\end{array}$ & $\begin{array}{c}\text { Sand } \\
(\%)\end{array}$ \\
\hline 1 & 7.8 & 26.5 & 65.7 \\
2 & 16.5 & 41.1 & 42.4 \\
$4^{\prime}$ & 10.0 & 39.1 & 50.9 \\
5 & 20.2 & 20.3 & 59.5 \\
$5^{\prime}$ & 14.2 & 27.4 & 58.4 \\
$5^{\prime \prime}$ & 13.6 & 30.3 & 56.1 \\
7 & 10.1 & 24.2 & 65.7 \\
9 & 20.7 & 22.8 & 56.5 \\
10 & 5.0 & 30.3 & 64.7 \\
13 & 10.3 & 23.0 & 66.7 \\
16 & 9.0 & 23.9 & 67.1 \\
21 & 1.5 & 3.5 & 95.0 \\
22 & 7.3 & 19.5 & 73.2 \\
\hline
\end{tabular}

地点は第 3 図，地点名は第 7 図の説明文参照。ただ し, 4' はマヤクボカール下流側のアウトウォッシュ $(2,450 \mathrm{~m}), 5^{\prime}$ はマヤクボ沢モレーン（ラテラルモ レーン) $(2,350 \mathrm{~m}), 5^{\prime \prime}$ はマヤクボ沢モレーン（下 流部ラテラルモレーン) $(2,320 \mathrm{~m})$ である。

ティルの分析結果は，Loc. 1 を除きティルのマト リックスとして十分な值を得た。Loc. 1 の粘土含有 量は，他のティルに比べて低い。これは，礫種のち がい（第 7 図）が関係しているのかもしれない。

アウトウォッシュや段丘䃯層の分析結果の中で, Loc. $4^{\prime}$ やLoc. 9 はティルの值とほとんど変わらな い。Loc. $4^{\prime}$ は第 3 図に位置を示す通り，Loc. 4 のモ レーンと近接していることを考慮すれば理解でき る。また Loc. 9 は大沢小屋付近の段丘状堆積物であ るが，この結果だけからみると平林（1984）が言う ようにこの堆積物はティルなのかもしれない。他 の Locs. 7, 13, 16 は粘土の含有量が帛ぼ 10\%, シル トの含有量も $25 \%$ 程度で, これらの地点の堆積物を アウトウォッシュと考えても問題ないであろら。 Loc. 22 はアウトウォッシュの Loc. 7 と形成年代が 同じと考皇た段丘状の堆積物であるが，Loc. 7 と距 離的に離れていることから，アウトウォッシュとい らよりもむしろ段丘礫層として形成されたものであ ろら。 
3）走査型電子顕微鏡による石英砂粒表面組織の 観察結果

前述した粒度分析と同じ方法で採取した堆積物の マトリックス中の石英砂粒の表面組織を，小疇ほか （1974），清水（1975），小疇注か（1978）飞従って走 查型電子顕微鏡によって観察した。ただし粒度分析 を行った砂粒は，表面に新たな傷がついた可能性も あるので，同じ地点における他のサンプルを使用し た。結果を第 2 表に示す。

これらの中で，小疇湶か(1974)が示した基準，す なわち石英砂粒の $50 \%$ 以上に氷河性の痕跡が認め られたものは，Locs. 1，1'，5，5'，5”である。それらは すべて，地形や堆積物の層相からティルと判断した ものである。特にグランドモレーンと判断した Loc. 5 は， $65 \%$ と高い値を示した。一方ティルと判断し た堆積物のなかで, Loc. 2 は非常に低い值を示した。 Loc. 2 はカール底のモレーンなので，伊藤(1982)が 報告したように，このティルは氷河流動によって運 搬される距離が短かったため，石英砂粒は十分な摩 耗を受けなかったものと考光られる。

上記の傾向は，マヤクボカール底より少し下流の アウトウォッシュと判断したLoc. 4'にも表われて 打り,他のアウトウォッシュの各地点の結果と比べ,

第 2 表 走查型電子顕微鏡による石英砂粒表面組織 の観察結果

\begin{tabular}{c|c|c||c}
\hline \hline Loc. & Total & Glacial & Glacial (\%) \\
\hline 1 & 24 & 13 & 54.2 \\
$1^{\prime}$ & 26 & 14 & 53.8 \\
2 & 27 & 6 & 22.2 \\
$4^{\prime}$ & 28 & 6 & 21.4 \\
5 & 20 & 13 & 65.0 \\
$5^{\prime}$ & 20 & 11 & 55.0 \\
$5^{\prime \prime}$ & 24 & 13 & 54.2 \\
7 & 20 & 8 & 40.0 \\
9 & 22 & 8 & 36.4 \\
13 & 23 & 8 & 34.8 \\
16 & 23 & 11 & 47.8 \\
22 & 22 & 9 & 40.9 \\
\hline
\end{tabular}

地点は第 3 図を参照。
低い值 (21.4\%) となっている。この Loc. 4' 以外で, アウトウォッシュや段丘礫層として判断された Loc. 7, 9, 13, 16, 22 は, ほぽ 35\% から 40\% 程度の值 となった。粒度分析で粘土の含有量が特に多かった Loc. 9 は，石英砂粒の観察結果からは積極的にティ ルと判断し難い。

\section{IV. 考察}

\section{1. 南北両斜面の水河地形と地形的雪線高度の比 較}

本研究で認めた 4 回の水河前進期ごとに, 水食壁 の下限高度とターミナルモレーンの平均高度を流域 別に委とめ, 第 8 図に示した。これらの值の中で, 特 に雪崩によって涵養された氷河によって形成された ものは*で示し, 平均値の計算の際には除外した。雪 崩涵養型の氷河は，例兄ば急傾斜地域のような局地 的な地形条件を反映して形成されることが多く（五 百沢, 1979), これらの氷河分布に基づく雪線高度は, 平均的な雪線高度より著しく低い値を示すことがあ るからである。

この図に示される通り，南側斜面に分布しないIV 期のものを除き, 水食壁の末端高度はI 期, II 期, III 期ともに北側斜面より南側斜面の方が高くなたそ の差はI期で $75 \mathrm{~m}$, II 期で $13 \mathrm{~m}$, III 期で $48 \mathrm{~m}$ と なっている。ところがターミナルモレーンの平均高 度を比較すると，I 期では南側斜面の方が $80 \mathrm{~m}$ 高い ものの, II 期や III 期では 25 45 m 北河斜面の方が 高くなり，上記の水食壁の末端高度の傾向と一致し ない。そこで, 水食壁の末端高度やターミナルモレー ンの平均高度を比較するょりも，むしろ，それらの 位置から算出できる地形的雪線高度を比較した方が 良いのではないかと考光た。

地形的雪線高度の算出については，まずターミナ ルモレーンと水食壁の位置, 特にU 字谷谷壁上端の 位置と連続性とから水河の分布を各水河前進期ごと に復元した。次に，氷河涵養域と消耗域とを $3: 1$ に 


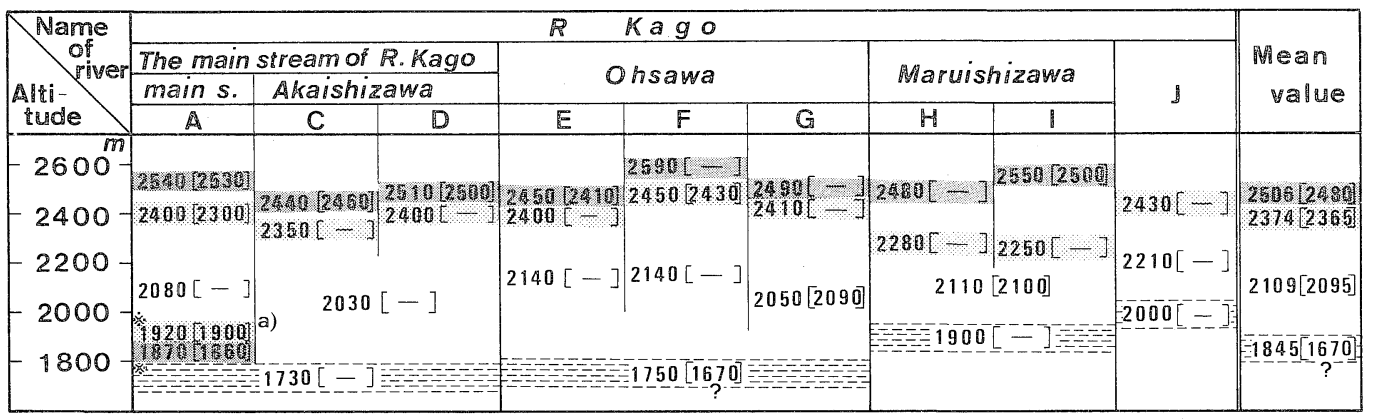

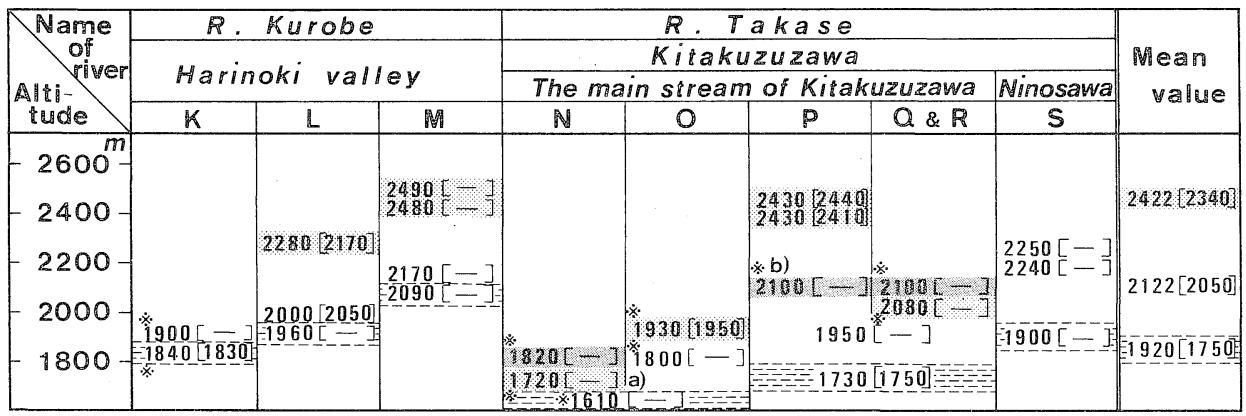

$1 ; 1900[1990] 2 ; 1990[1990] \quad 3 ; 1990[1990] \quad 4 ; 1990[1990] 5 ;[-] \quad 6 ; \dot{x}$

第 8 図南北両側斜面に扣ける氷食壁高度とターミナルモレーン平均高度 図中の数字は氷食壁末端高度 $(\mathrm{m})$ を，[ ] 内の数字はターミナルモレーン平均高度 $(\mathrm{m})$ を示す。 1:IV 期， 2：III 期， $3:$ II 期，4：I 期， 5: 分布なし，6：雪崩涵養型水河によって形成されたこ とが明らかなもの，a）II 期の高度もこのIII 期と同じ， b ）：III 期の高度もこのIV 期と同じ。 $\mathrm{A} \sim \mathrm{S}$ の位置は第 3 図と第 9 図を参照。

分ける Brückner の方法 (野上，1970)を便宜的に使 用し，地形的雪線高度を図上で求めた。すなわち，あ る氷河の分布範囲が決委ると，方眼紙によってその 全面積を求め, 下流側からその面積の $1 / 4$ に相当す る等高線の位置を求め, 数值を読み取る作業を行っ た。ここで方眼紙を用いたのは, 等高線の位置によっ て上記の $1 / 4$ の面積が相当変化するためであり, 他 の簡易的な方法では誤差が生じると考皇たからであ る。

第 9 図にこの方法によって求めた各水河前進期の 氷河の分布と地形的雪線高度の值を示す。当地域の 場合は，新しい氷河前進期注ど氷河が上流側に縮小 したかたちで分布していたと考壳られるので，I期 の水河分布範囲には II 期の範囲が含まれるといっ た表示方法となっている。また，ある水河前進期に
招いて，氷河が上流側と下流側とに分断したかたち で発達していたと判断される場合も，それぞれにつ いて表示した。

次にこ机らの水河分布面積と地形的雪線高度を第 3 表になとめた。氷河分布面積は, 各前進期とも北側 斜面の方が広い。李た分布面積の減少率を両斜面で 比較したとこう, 特に南側斜面では, II 期から III 期 にかけて約 $1 / 4$ 之異常に縮小し, IV 期では消滅する ことがわかる。地形的雪線高度については, I 期や II 期では北側斜面の方が $27 \sim 103 \mathrm{~m}$ 高く, III 期は南側 斜面の方が $5 \mathrm{~m}$ 高い結果となり, 氷食壁末端高度平 均值やターミナルモレーン平均高度平均值とは異 なった傾向が認められた。すなわち I 期や II 期で は, 北側斜面上りもむしろ南側斜面の方で地形的雪 線高度が低くなる傾向が指摘できる。このような傾 


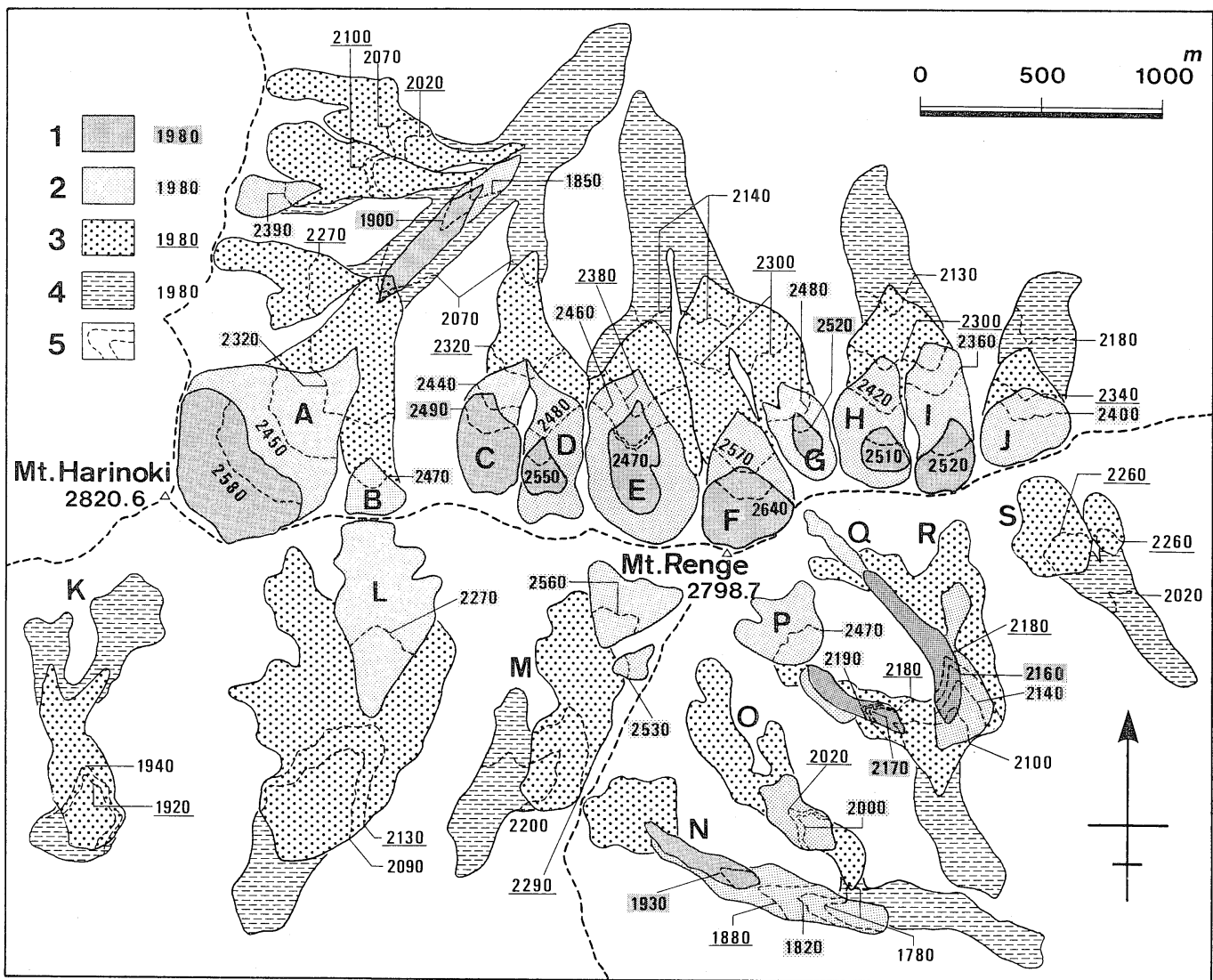

第 9 図 各水河前進期に扝ける水河復元図及び地形的雪線高度の位置と標高

1：IV 期の水河分布範囲之その地形的雪線高度，2：III 期，3：II 期，4：I期，5：地形的雪線高 度の位置

向が認められたことは，雪崩溷養型のものを除去し たとはいえ，南側斜面の谷頭部には北側斜面のよう なカール状地形がなく, 南側斜面で復元した氷河は， 実際には雪崩涵養型の氷河であった可能性を示すも のであろら。このことは第 9 図に認められるように, 南側斜面の水河が谷頭部よりむしろ中流部で広が り, しかも細長く分布していること, 氷河分布面積 が南側斜面よりむしろ北側斜面でかなり大きい值と なっていることからも裏付けられる。したがってI 期や II 期の両側斜面に和ける地形的雪線高度のち がいは，気候的な要因よりむしろ地形的・位置的な 制約に基づくものといえよう。

\section{2. 槍・穂高連峰の地形的雪線高度との比較}

北アルプスに拈ける氷期の水河分布の地域的なち がいを把握するため, 槍・穂高連峰に和ける地形的 雪線高度(伊藤，1982) と比較することを試みた。す ず当地域の南北両斜面, 及び槍・穂高連峰の東西両 斜面に発達した全ての水河の地形的雪線高度と氷河 分布面積との関係を調べた。その結果, 第 10 図に示 されるように両地域の分布域には明瞭な境界（図中 央部を斜めに横切る破線）が存在することが明らか となった。ただ一地点, 当地域の範囲に入ってくる 槍・穂高連峰の氷河は，横尾根カールの水河である。 この一地点を除けば，当地域は槍・穂高連峰と比べ, 地形的雪線高度は低く, 氷河分布面積はより狭く 
なっていることがわかる。いいか觉机ば，当地域の 氷河は，槍・穂高連峰の氷河々比べ，標高の低いと ころに発達したために，気候条件が悪く，そのため 氷河の発達規模が小さくなったのではなかららか。

次に両地域の地形的雪線高度の差が, 両地域の気 温差で説明できないかどらかについて検討を行っ た。この場合，各氷河前進期毎に気温差を算出する ため, 両地域の氷河前進期の対比を行う必要がある。 両地域とも，水河前進期を決定する絶対年代資料が 得られていないため, 対比は今後の課題となるが,こ こでは氷河地形の分布, 氷河の消長の様子, 地形の 開析状況などから対比を試みた。すなわち両地域と も同じ 4 回の氷河前進期が認められ，氷河の消長の 様子が一致していることから，I期：滝谷期(一)俣 期), II 期 : 槍平期 (ババ平期), III 期 : 飛驒沢期 I
（槍沢期 I），IV 期 : 飛驒沢期 II（槍沢期 II）と対比 できる可能性がある。また氷河地形の開析の状況を 主に考慮すると, I 期： 槍・穂高連峰では未確認, II 期 : 滝谷期 (一ノ俣期), III 期 : 槍平期 (ババ平期), IV 期 : 飛驒沢期 I と II（槍沢期 I と II）飞対比でき る場合も考光られる。しかしここでは試みとして, 前 者の場合について比較してみる。

各水河前進期の地形的雪線高度の平均值は, 槍。 穂高連峰では東西両斜面の平均値, 当地域では南北 両斜面の平均值としてそれぞれ算出した（第 4 表）。 ただし当地域ではIV 期に抢ける南側斜面の值がな いため, その地形的雪線高度として主稜線平均高度 の標高約 $2,600 \mathrm{~m}$ を採用した。これは南側斜面の IV 期の地形的雪線高度がこの值よりも低ければ，氷河 が形成されたと判断できるためで，したがってこの
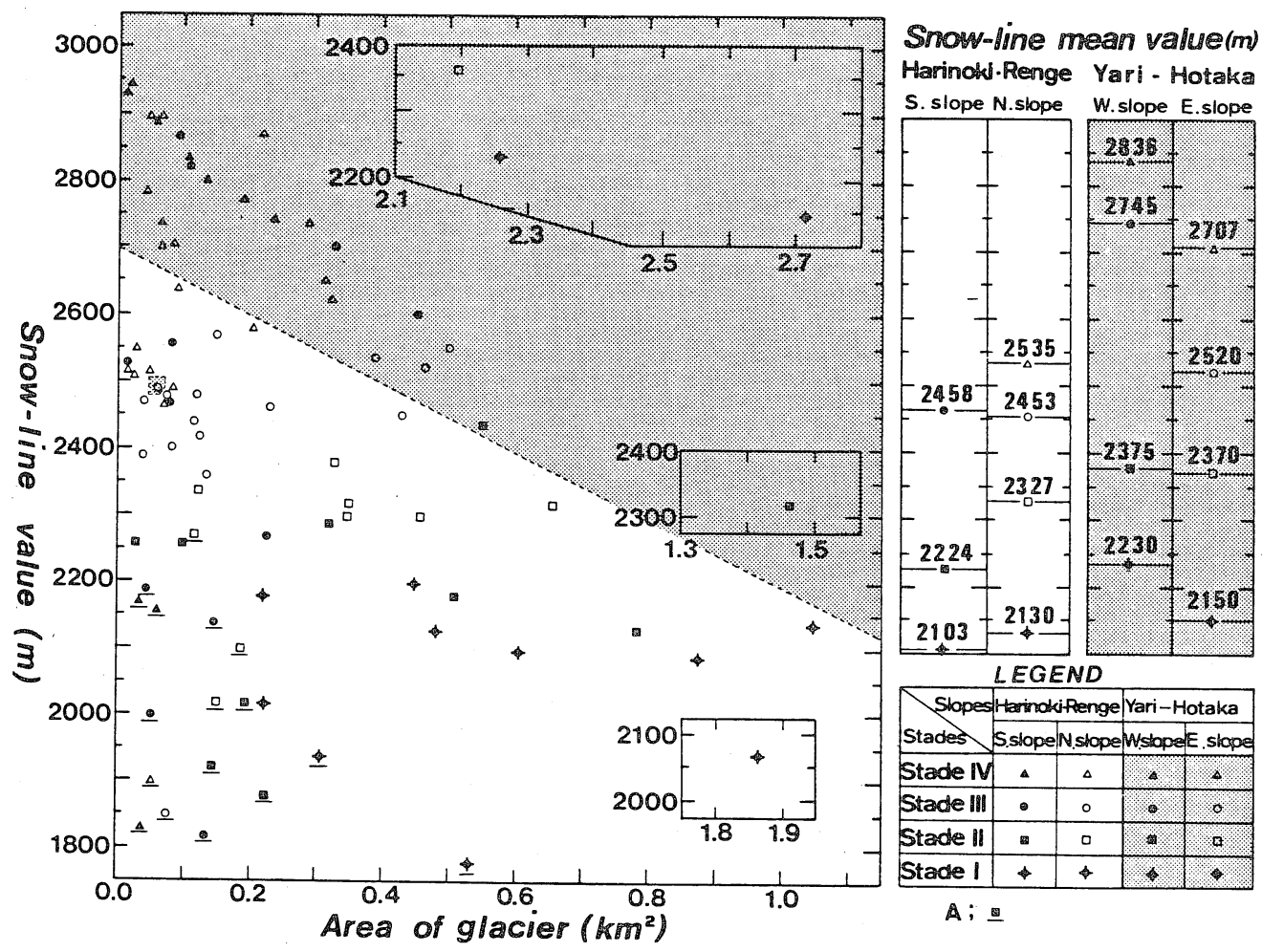

第 10 図 針ノ木岳・蓮華岳周辺之槍・穂高連峰との各水河前進期飞招ける水河分布面積と雪線高度との関係 A ; 記号の下にアンダーラインを引いたものは，明らかに雪崩涵養型の水河と判断されるもの。 
第 3 表 各水河前進期に括ける南北両側斜面の水河分布面積と雪線高度の比較

\begin{tabular}{|c|c|c|c|c|c|c|c|c|c|c|c|c|c|c|c|}
\hline \multirow{4}{*}{$\begin{array}{c}\text { Name } \\
\text { of } \\
\text { river } \\
\text { Stades }\end{array}$} & \multicolumn{14}{|c|}{ R. Kago } & \multirow{4}{*}{$\begin{array}{l}\text { Total } \\
\text { Mean } \\
\text { yalue }\end{array}$} \\
\hline & \multicolumn{8}{|c|}{ The main stream of R. Kago } & \multirow{2}{*}{\multicolumn{3}{|c|}{ Ohsawa }} & \multirow{2}{*}{\multicolumn{2}{|c|}{ Maruishizawa }} & \multirow{3}{*}{ J } & \\
\hline & \multicolumn{3}{|c|}{ main stream } & \multirow{2}{*}{\multicolumn{3}{|c|}{$\begin{array}{l}\text { Western area of } \\
\text { down stream }(\mathrm{A}, \mathrm{B})\end{array}$}} & \multicolumn{2}{|c|}{ Akaishizawa } & & & & & & & \\
\hline & A & $\mathbf{B}$ & down st. & & & & C & $\mathrm{D}$ & $E$ & $F$ & $\mathbf{G}$ & $H$ & 1 & & \\
\hline \multirow{2}{*}{ Stade TV } & 0.204 & & 0.055 & & & & 0.083 & 0.027 & 0.069 & 0.091 & 0.014 & 0.026 & 0.048 & & 0.855 \\
\hline & 25800 & & 1900 & & & & 2490 & 2550 & 2470 & 2640 & .26 .20 & 2510 & 2520 & & 2535 \\
\hline \multirow{2}{*}{ Stade III } & 0.427 & 0.041 & 0.078 & & 0.038 & & 0.116 & 0.120 & 0.231 & 0.149 & 0.075 & 0.125 & 0.135 & 0.085 & 1.504 \\
\hline & 2550 & 2470 & 1.850 & & 2380 & & 24.40 & 2480 & 2460 & 2570 & 2480 & 2420 & 2360 & $2 \mathrm{ag0}$ & 2453 \\
\hline \multirow{2}{*}{ Stade II } & \multicolumn{2}{|c|}{0.657} & 0.078 & 0.116 & 0.187 & 0.151 & \multicolumn{2}{|c|}{0.350} & 0.327 & \multicolumn{2}{|c|}{0.457} & \multicolumn{2}{|c|}{0.348} & 0.123 & 2.262 \\
\hline & \multicolumn{2}{|c|}{2320} & 18.50 & 2270 & 2100 & 2020 & \multicolumn{2}{|c|}{2320} & 23.80 & \multicolumn{2}{|c|}{2300} & \multicolumn{2}{|c|}{2300} & 2340 & 2327 \\
\hline \multirow{2}{*}{ Stade I } & \multicolumn{6}{|c|}{1.866} & & & \multirow{2}{*}{\multicolumn{3}{|c|}{$\begin{array}{l}1.045 \\
2140\end{array}$}} & \multicolumn{2}{|c|}{0.479} & 0.222 & 3.612 \\
\hline & \multicolumn{8}{|c|}{2070} & & & & \multicolumn{2}{|c|}{2130} & 2180 & 2130 \\
\hline
\end{tabular}

\begin{tabular}{|c|c|c|c|c|c|c|c|c|c|c|c|c|}
\hline \multirow{4}{*}{$\begin{array}{c}\text { Name } \\
\text { of } \\
\text { river } \\
\text { Stades }\end{array}$} & \multicolumn{4}{|c|}{ R. Kurobe } & \multirow{2}{*}{\multicolumn{7}{|c|}{$\frac{\text { R. Takase }}{\text { Kitakuzuzawa }}$}} & \multirow{4}{*}{$\begin{array}{l}\text { Total } \\
\text { Mean } \\
\text { value }\end{array}$} \\
\hline & \multirow{2}{*}{\multicolumn{2}{|c|}{ Marinoki }} & \multirow{2}{*}{\multicolumn{2}{|c|}{ valley }} & & & & & & & & \\
\hline & & & & & \multicolumn{5}{|c|}{ eam of Kirakuzuzawa } & \multicolumn{2}{|c|}{ Nino sawa } & \\
\hline & K & $\mathrm{L}$ & \multicolumn{2}{|c|}{ m } & N & 0 & \multicolumn{2}{|c|}{$P$} & $Q \& R$ & $\mathrm{~s}$ & & \\
\hline \multirow{2}{*}{ Stade $\mathbb{N}$} & & & & & 039 & & & 0.034 & 0.061 & & & \\
\hline & & & & & 1830 & & & 2130 & 2160 & & & \\
\hline \multirow{2}{*}{ Stade III } & & 0.223 & 0.083 & 0.015 & 0.136 & 0.053 & 0.080 & 0.046 & 0.147 & & & 0.401 \\
\hline & & 2270 & 2560 & 2530 & 1820 & 2000 & 2470 & 2190 & 2140 & & & 2458 \\
\hline \multirow{2}{*}{ Stade II } & 0.146 & 0.785 & \multicolumn{2}{|c|}{0.318} & 0.225 & 0.195 & \multicolumn{3}{|c|}{0.508} & 0.100 & 0.028 & 1.739 \\
\hline & 1920 & 2.3 .0 & \multicolumn{2}{|c|}{2290} & 1880 & 2020 & \multicolumn{3}{|c|}{2180} & 2260 & 2250 & 2224 \\
\hline \multirow{2}{*}{ Stade I } & 0.308 & 0.873 & \multicolumn{2}{|c|}{0.448} & \multicolumn{2}{|c|}{0.533} & \multicolumn{3}{|c|}{0.604} & \multicolumn{2}{|c|}{0.223} & 2.148 \\
\hline & 1340 & 2090 & \multicolumn{2}{|c|}{2200} & \multicolumn{2}{|c|}{1780} & \multicolumn{3}{|c|}{2100} & \multicolumn{2}{|c|}{2020} & 2103 \\
\hline
\end{tabular}

Area of glacier

$\left.(\mathrm{km})^{2}\right)$

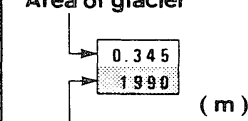

Snow-line value

Accumulation area : Ablation area $=3:$

1)

A S の位置は第 3 図と第 9 図を参照。

1) は雪崩涵養型の氷河によって形成されたことが明らかなもの。したがっ て, 右端の氷河面積合計値や地形的雪線高度平均値の算出の際には, この値は 使用していない。

第 4 表 各水河前進期に拈ける針ノ木岳・蓮華岳周辺と槍・穗高連峰との気温差

\begin{tabular}{|c|c|c|c|c|}
\hline \multirow[b]{2}{*}{ Stades } & \multicolumn{2}{|c|}{ Mean altitude of Snow-line } & \multirow{2}{*}{$\begin{array}{c}\text { Difference } \\
\text { of } \\
\text { Altitude } \\
\text { (A) - (B) }\end{array}$} & \multirow{2}{*}{$\begin{array}{c}\text { Difference } \\
\text { of } \\
\text { Temperature } \\
\left(0.5^{\circ} \mathrm{C} / 100 \mathrm{~m}\right)\end{array}$} \\
\hline & $\begin{array}{l}\text { (A) Yri-Hotaka } \\
\text { Moutain } \\
\text { Range }\end{array}$ & $\begin{array}{l}\text { (B) Harinoki- } \\
\text { Renge } \\
\text { Region }\end{array}$ & & \\
\hline Stade IV & $2,772 \mathrm{~m}$ & $\begin{array}{l}* 2,568 \mathrm{~m} \\
(2,535 \mathrm{~m})\end{array}$ & $\begin{array}{c}204 \mathrm{~m} \\
(237 \mathrm{~m})\end{array}$ & $\begin{array}{l}1.0^{\circ} \mathrm{C} \\
\left(1.2^{\circ} \mathrm{C}\right)\end{array}$ \\
\hline Stade III & $2,633 \mathrm{~m}$ & $2,456 \mathrm{~m}$ & $177 \mathrm{~m}$ & $0.9^{\circ} \mathrm{C}$ \\
\hline Stade II & $2,373 \mathrm{~m}$ & $2,276 \mathrm{~m}$ & $97 \mathrm{~m}$ & $0.5^{\circ} \mathrm{C}$ \\
\hline Stade I & $2,190 \mathrm{~m}$ & $2,117 \mathrm{~m}$ & $73 \mathrm{~m}$ & $0.4^{\circ} \mathrm{C}$ \\
\hline
\end{tabular}

*印は南側斜面の地形的雪線高度を主稜線高度平均值の約 $2,600 \mathrm{~m}$ として計算した。 （）は北側斜面だけの值を使用。

值は，南側斜面で推定されるIV 期の地形的雪線高 度の最低值といらことになる。また（）で, 北側斜 面に打けるIV 期の地形的雪線高度を採用した場合 の結果を示した。そこで各水河前進期ごとに地形的 雪線高度の差を計算し, 気温減率を便宜的に $0.5^{\circ} \mathrm{C} /$ $100 \mathrm{~m}$ として気温差を算出すると第 4 表の結果と なった。すなわち, I 期で $0.4^{\circ} \mathrm{C}$, II 期で $0.5^{\circ} \mathrm{C}$, III 期 で $0.9^{\circ} \mathrm{C}$, IV 期で $1.0(1.2)^{\circ} \mathrm{C}$ とれぞれ当地域の方 が気温が低いことになる。
最後に, 現在の両地域の気温差を考慮してみたい。 槍・穂高連峰及び当地域の周辺で, 通年の気温デー タが得られている地点は, 前者の地域で松本, 後者 の地域で大町があげられる。長野県気象年報（日本 気象協会長野支部，1974, 1975, 1976)によれば, 1974 ～ 1976 年の年平均気温と 8 月の月平均気温の 3 ケ 年平均值は第 5 表の通りで, 松本と大町との気温差 は年平均で $2.1^{\circ} \mathrm{C}, 8$ 月で $2.0^{\circ} \mathrm{C}$ とな。この值につ いて, 両地点の標高差を $0.5^{\circ} \mathrm{C} / 100 \mathrm{~m}$ の気温減率で 
第 5 表 現在の松本と大町, 槍ヶ岳と冷池との気温差

\begin{tabular}{|c|c|c|c|c|}
\hline & $\begin{array}{c}\text { (A) } \\
\text { Matsumoto } \\
(610 \mathrm{~m})\end{array}$ & $\begin{array}{c}\text { (B) } \\
\text { Ohmachi } \\
(789 \mathrm{~m})\end{array}$ & $\begin{array}{c}\text { (C) } \\
\text { Difference } \\
\text { of Temp. } \\
(\mathrm{A})-(\mathrm{B})\end{array}$ & $\begin{array}{l}\text { (D) } \\
\text { Difference } \\
\text { of Temp. } \\
\text { (C) }-0.9^{\circ} \mathrm{C}\end{array}$ \\
\hline Jan.-Dec. & 11.2 & 9.1 & 2.1 & 1.2 \\
\hline \multirow[t]{2}{*}{ Dug. } & 25.2 & 23.2 & 2.0 & 1.1 \\
\hline & $\begin{array}{c}\left(\mathrm{A}^{\prime}\right) \\
\text { Mt. Yari } \\
(3,050 \mathrm{~m})\end{array}$ & $\begin{array}{c}\left(\mathrm{B}^{\prime}\right) \\
\text { Tsumetaike } \\
(2,410 \mathrm{~m})\end{array}$ & $\begin{array}{c}\left(\mathrm{C}^{\prime}\right) \\
\text { Difference } \\
\text { of Temp. } \\
\left(\mathrm{A}^{\prime}\right)-\left(\mathrm{B}^{\prime}\right)\end{array}$ & $\begin{array}{c}\left(\mathrm{D}^{\prime}\right) \\
\text { Difference } \\
\text { of Temp. } \\
\left(\mathrm{C}^{\prime}\right)+3.2^{\circ} \mathrm{C}\end{array}$ \\
\hline Jan.-Dec. & - & - & - & - \\
\hline Aug. & 10.9 & 12.3 & -1.4 & 1.8 \\
\hline
\end{tabular}

松本と大町との標高差は $179 \mathrm{~m}$ であり, 気温減率を $0.5^{\circ} \mathrm{C} / 100 \mathrm{~m}$ とする と, $0.9^{\circ} \mathrm{C}$ の気温差に相当する。また槍ケ岳と冷池の場合は, $3.2^{\circ} \mathrm{C}$ の気温 差になる。

補正すると, 大町の方が年平均で $1.2^{\circ} \mathrm{C}, 8$ 月で $1.1^{\circ} \mathrm{C}$ それぞれ低くなる。

一方，夏季については上記と同じ資料から，山岳 気象データが得られる。槍ケ岳及び当地域に最も近 い冷池の気温データによれば，上記の同じ時期の 8 月の月平均気温は第 5 表の通りで, 上記と同じょう に両地点の標高差を補正すると, 冷池の方が $1.8^{\circ} \mathrm{C}$ 低くなる。

以上の結果から, 現在では平地で $1.1^{\circ} \mathrm{C}$ から $1.2^{\circ} \mathrm{C}$, 山岳地域で $1.8^{\circ} \mathrm{C}$ 程度, 槍・穂高連峰より当 地域の方が気温が低いことになる。この値(第 5 表) と, 前述した各氷河前進期に打ける気温差(第 4 表) とを比べると，両者にそれほど大きな差が認められ ないことになる。特に IV 期の気温差は, 現在とほぼ 同じ気温差といらことがわかる。したがって, 両地 域の地形的雪線高度の差は, 両地域の気温の差, す なわち緯度のちがいによって説明でさる。一方, 前 述したように, 当地域の地形的雪線高度が低いのに, 氷河の発達規模が小さいことは, 山頂高度が低いた めに, 氷河涵養域が広くならなかったことと, カー ルをつくるようなゆるやかな谷頭部を欠くといった 地形的制約によるものであろう。

\section{V。まとめ}

本研究結果は, 次のようによとめられる。

（1）針ノ木岳・蓮華岳周辺の氷河地形は, 第 3 図 のように分布していることが明らかになり，これら のモレーンやアウトウォッシュ, 水河研磨面状の水 食壁や U 字谷谷壁上端の高度や分布状況から, 当地 域では古い方から針ノ木 I 期，針ノ木 II 期，針ノ木 III 期, 針ノ木 IV 期の 4 回の氷河前進期が認められ た。

（2）上記 4 回の水河前進期ごとの氷河の分布を 復元し, 氷河分布面積と地形的雪線高度とを算出し, 主稜線の北側斜面と南側斜面に招けるそれらの結果 を比較した。その結果, 氷河分布面積は各前進期と も北側斜面の方が広く, 地形的雪線高度については, I 期や II 期では北側斜面の方が高いものの, III 期や IV 期になると南側斜面の方が高くなる。ただし，IV 期に抢ける南側斜面の雪線高度は山稜高度上り高く なるため, 南側斜面ではIV 期に招いて承河は形成 されなかったものと考克られる。

（3）当地域と槍・穂高連峰に抢ける氷河分布面積 や地形的雪線高度 (伊藤, 1982) を比較してみると, 
当地域の方が氷河分布面積が小さいにもかかわら ず,地形的雪線高度が低いことが明らかとなった。地 形的雪線高度が低いことは，両地域の気温差，すな わち緯度の差で説明できる。つ委り，I期（滝谷期） で $0.4^{\circ} \mathrm{C}$, II 期（槍平期）で $0.5^{\circ} \mathrm{C}$, III 期（飛驒沢期 I）で $0.9^{\circ} \mathrm{C}, \mathrm{IV}$ 期（飛驒沢期 II）で $1.0^{\circ} \mathrm{C}$ 当地域の 方が槍・穂高連峰より気温が低いといら結果による ものである。しかし，当地域の氷河分布の面積の方 が小さいといらことは, 当地域の方が山頂高度が低 いために，氷河涵養域が広くならなかったことと， カール地形をつくるよらなゆるやかな谷頭部を欠く といった地形的制約によって, 氷河の発達がさまた げられたためと考光られる。

\section{謝辞}

本稿作成に際し, 北海道大学環境科学研究科の小野有 五助教授に御指導賜り, 本稿を読んでいただいた。北陽建 設の平林照雄顧問, 国立防災科学技術センターの清水文 健主任研究官, 東京大学地理学教室の松本 淳助手には 貴重な御助言を賜った。現地調查では松本 淳助手に御 協力いただいた。以上の方々に厚く御礼申し上げます。

\section{文献}

土質工学会 (1983)：粒度試験。土質工学会編：土の試 験実習書一第一回改訂版一, 43-54.

Flint, R.F. (1971): Glacial and Quaternary geology. Wiley.

平林照雄 (1984): 大町市の地形地質. 大町市史編纂委 員会編：大町市史，3-332.

Hoshiai, M. and Kobayashi, K. (1957): A theoretical discussion on the so-called "Snow Line", with reference to the temperature reduction during the Last glacial age in Japan. Japanese Jour. Geol. and Geogr., 28, 61-75.

五百沢智也 (1963)：写真判読による日本アルプスの水 河地形。日本地理学会学術大会配布資料, 1-8. 五百沢智也 (1973)：後立山連峰北部の氷河地形。大町 山岳博物館編: 北アルプス博物誌, II 植物・地学, 258-264.

五百沢智也(1974): 空からの水河地形調查. 地理, 19, no. 2. 38-50.

五百沢智也(1979): 鳥瞰図譜 日本アルプス. 講談社.
今村学郎 (1940)：日本アルプスと水期の水河. 岩波書 店.

今西錦司（1929）：剣沢の万年雪に就いて。地球，11, 267-282.

石川一吉 (1982): 北アルプス鹿島槍ケ岳一鳥帽子岳付 近の火成岩類の地質. 地質雑, 88, 215-230.

伊藤真人 (1982): 北アルプス南部, 蒲田川右俣谷の氷 河地形. 地学雑, 91, 88-103.

Ito, M. and Vorndran, G. (1983) : Glacial geomorphology and snou-lines of younger Quaternary around the Yari-Hotake Mountain Range, Northern Alps, Central Japane. Polarforshung, 53, 75-89.

伊藤真人・正木智幸 (1987)：後立山連峰, 鹿島槍ヶ岳, 大冷沢流域に括活る氷河地形々氷河前進期。地理 評, 60 (Ser. A), 567-592.

小疇 尚・杉原重夫・清水文健・宇都宮陽二朗・岩田修 二・岡沢修一 (1974) : 白馬岳の地形学的研究. 駿 台史学, 35, 1-86.

小疇 尚・杉原重夫・清水文健・下川和夫（1978）：水 河堆積物中の石英砂粒表面組織。明治大学人文科 学研究所紀要, 17, 1-10.

小疇 尚 (1983)：氷河・周水河地形からみた日本の最 終水期. 月刊地球， 5, no. 1, 13-19.

小林国夫 (1964)：針ノ木岳周辺の地質と地形。日本自 然保護協会調查報告， 11，30-41.

小林国夫・星合 誠 (1955)：日本に㧍ける氷期㧍よび 現在の雪線. 地球科学, $21,1-7$.

町田 洋・新井房夫 (1976)：広域に分布する火山灰 一姶良 Tn 火山灰の発見とその意義一. 科学, 46, 339-347.

町田 洋 (1979)：信濃川上流々姫川の自然と歴史．松 本砂防工事事務所編：松本砂防工事事務所のあゆ 及。建設省, 1-76.

松本砂防工事事務所 (1976)：高瀬川流域地質図（5 万 分の 1 地質図及び同説明書).

日本気象協会長野支部 $(1974,75,76)$ : 長野県気象年 報, 昭和 49 年, 50 年, 51 年.

野上道男 (1970)：雪線の定義とその決定法。第四紀研 究, 9, 7-16.

小野有五・平川一臣（1974）：ヴュルム氷期における日 高山脈周辺の地形形成環境. 地理評, 48, 1-26.

Ono, Y. (1981): Mass balance of the Pleistocene alpine glacier in the Japanese Alps. Ann. Rep., Inst. Geosci., Univ. Tsukuba, 7, 35-38. 
小野有五 (1982)：氷河地形による最終水期の降雪量の

復元と海水準変動. 第四紀研究, 21，229-243.

小野有五 (1985)：最終水期の地形環境之気候. 月刊地

球, 7 , no. $6,344-348$.

式 正英 (1956)：日本の山地地形。多田文男・石田龍

次郎編：現代地理講座, 2, 山地の地理. 河出書房,
$80-96$.

清水文健 (1975)：白馬岳松川谷に抢ける氷河体積物中 の石英砂粒表面組織. 式 正英編：日本の水期の 諸問題. 古今書院, 72-87.

\section{Glacial landforms and the height of pleistocene orographic snowline around Mt. Harinoki and Mt. Renge, Northern Japanese Alps}

\section{Mahito ITO* and Tomoyuki MASAKI**}

The authors investigeted in detail the glacial landforms in the area around Mt. Harinoki $(2,820.6 \mathrm{~m})$ and Mt. Renge $(2,798.7 \mathrm{~m})$, through field surveys and aerophoto-interpretation. Judging from the location of terminal moraines, outwash terraces, trough edges, glacial polishes, and the difference of dissection of glacial landforms, four glacial stades were recognized. They were named, from the older to the younger, Harinoki I, II, III and IV stades respectively. The Harinoki I stade corresponds to a maximum glacial extent in this area, when several glaciers extended to about 1,600 or $1,700 \mathrm{~m}$ a.s.1.

The distribution of glaciers in each stade indicateds that the glacier extended more on the northern slope than on the southern slone in every stade. The mean altitude of orographic snowline on both slopes was estimated by using the Brückner's method. It was higher on the northern slope than on the southern slope in the I and II stades, while it was lower on the former than the latter in the III and IV stades.

By comparing the orographic snowline of each stade in this area to that in the Yari-Hotaka Mountain Range (Ito, 1982), the difference of air temperature in two areas was estimated as follows; The mean annual air temperature in this area is lower than in the Yari-Hotaka Moutain Range of about $0.4^{\circ} \mathrm{C}$ in the I stade (the Takitani stade), $0.5^{\circ} \mathrm{C}$ in the II stade (the Yaridaira stade), $0.9^{\circ} \mathrm{C}$ in the III stade (the Hidazawa stade I), and $1.0^{\circ} \mathrm{C}$ in the IV stade (the Hidazawa stade II) respectively. The value in the younger stade, for in the IV stade, is similar to the value at present $\left(1.2^{\circ} \mathrm{C}\right)$.

* Aerological Observatory, Japan Meteorological Agency

** Senior High School, Tokyo Gakugei University 